RESEARCH PAPER RP683

Part of Bureau of Standards Journal of Research, vol. 12, May 1934

\title{
A STUDY OF THE PROPERTIES OF MORTARS AND BRICKS AND THEIR RELATION TO BOND
}

\author{
By L. A. Palmer and D. A. Parsons
}

\section{ABSTRACT}

The water retaining capacity, transverse and compressive strengths, sorption, volume changes, and moduli of elasticity of 50 mortars and the absorption rate, moisture expansion, and transverse and compressive strengths of six makes of brick were studied. Also, 15 of the 50 mortars were used with the 6 makes of brick in tests of brick,mortar assemblages. The data indicate that the water retaining capacity of mortars and absorption rate of bricks were of primary importance in obtaining a good bond. The possible effects of brick and mortar properties on strength of bond in tension, bond durability, transverse strength of brick beams, and compressive strength of brick piers are discussed.

\section{CONTENTS}

I. Introduction

1. Purpose and scope

2. Definitions of terms used in this paper.

3. Materials

(a) Sand

(b) Cementing materials

(c) Bricks

II. Test procedure

1. Mortars

(a) Proportioning

(b) Use of flow table and suction apparatus

(c) Molding of test specimens

(d) Classification of test specimens

(e) Curing of specimens

2. Bricks

(f) Methods of test.

(a) Preparation for tests.

(b) Measurements

3. Brick mortar specimens

(a) Preparation of materials

(b) Method of forming test specimens

(c) Classification of tests

(d) Measurements

III. Results 1 Mortars

(a) Water retaining capacity

(b) Shrinkage during early hardening

(c) Volume changes subsequent to hardening

(d) Compressive and transverse strength

(e) Modulus of elasticity and extensibility

(f) Sorption

2. Bricks

(a) Absorption rates

(b) Compressive and transverse strength

(c) Expansion of bricks on wetting- 
III. Results-Continued.

3. Assemblages

(a) Strength of bond

(1) General considerations _.

(2) The effect of brick suction, the water retaining capacity of mortar and strength of mortar on bond strength

(3) The effect of shrinkage during early hardening of mortars on bond strength

(4) The combined effect of shrinkage during early hardening and compacting of mortar on a porous base on bond strength

(5) The effect of volume changes in mortar subsequent to hardening on bond strength

(6) The increase in bond strength with time

(7) Statistical treatment of bond strength data

(b) Durability of bond

(c) The transverse strength of brick beams _._._._.

(d) Compressive strength of brick piers

IV. Summary and conclusions

\section{INTRODUCTION}

\section{PURPOSE AND SCOPE}

It has been the consensus of opinion among recent writers $\begin{array}{llll}1 & 2 & 3 & 4\end{array}$ that the points in brickwork most accessible to the entrance of water are the junctures of brick and mortar. Laboratory data as well as field observations have supported this view.

Suggestions for improving the bond of mortar to bricks or other building units are numerous and conflicting. However, there has been a conspicuous lack of data. This is mainly because it is exceedingly difficult to carry on an investigation so comprehensive and exhaustive that all classes of the materials involved may be well represented in the study.

Unfortunately, the selection of materials from the standpoint of their mutual suitability has received too little attention. Obviously it will not suffice to consider the physical properties of either of the two materials, bricks or mortar, as unrelated to the other. Specifications for either material should be written with regard for the other.

The purpose of this investigation ${ }^{5}$ was, therefore, twofold. First, it was intended to make a survey, as wide as possible, of the physical properties of both mortars and bricks. Second, it was then proposed to find how these data are related to the bond with particular reference to water tightness of walls, assuming that improving the bond will improve the watertightness of the masonry.

It happened that a rather extensive survey of bricks from various sections of the United States was being completed ${ }^{6}$ at the time this study was begun. This earlier study made it possible to select, with a minimum of preliminary work, representative types of bricks.

\footnotetext{
1 F. O. Anderegg, Water-Tight Masonry, The Architectural Record, vol. 70, no. 3, pp. 202-207, 1931.

2 L. A. Palmer, Water Penetration through Brick-Mortar Assemblages, Jour. Clay Prod. Inst., vol. 1, pp. 19-31, Sept. 1931 .

3 L. B. Lent, Exterior Wall Construction, General Building Contractor, pp. 35-41, Feb. 1932.

4 Bulletin of the Boston Society of Architects, no. 3, Dec. 1931.

3 In order to save space some of the data are presented in the form of graphs showing average values. Tables giving the data in more detail may be obtained upon application to the Bureau of Standards, Washington, D.C.

ington, McBurney, J. W., and Lovewell, C. E., Strength, Water Absorption, and Weather Resistance of Build ing Bricks Produced in the United States; Proc. Am. Soc. for Testing Mats., vol. 33, part II, p. 636, 1933.
} 


\section{DEFINITIONS OF TERMS USED IN THIS PAPER}

Bond.-The attachment of brick to brick through the medium of an intervening mortar joint.

Bonding area.-The total area, in square inches, of the flat side of the smaller of two bricks adjacent to an intervening mortar joint.

Brick suction.-The amount of water, in grams, absorbed through the flatside of brick immersed $1 / 8$ inch in water for 1 minute.

Bond durability.- The resistance of bond to arbitrary weathering expressed as length of time required to destroy bond or as the lowering of bond strength.

Bond strength.- The tensils stress, expressed in pounds per square inch of bonding area, required to separate an assemblage of two bricks with intervening mortar joint.

Absorption.-A strictly physical process of a body taking up water and refers to mechanically held water.

Sorption. ${ }^{7}$ - Refers to moisture added to a body by any or all of the three processes: Absorption (physical), adsorption (physicochemical), and hydration (chemical).

Water retaining capacity. - The resistance of a freshly mixed mortar to the loss of water by filtration. ${ }^{8} 9$ In this paper the water-retaining capacity is expressed by the flow on the 10-inch table after suction ( 2 inches of mercury) for 1 minute, on a standard porous base (see table 2).

\section{MATERIALS}

(a) SAND

Fairly clean Potomac River mortar sand that had passed a no. 8 sieve was used in all tests. The sieve analysis of this sand was as follows:

\begin{tabular}{|c|c|c|}
\hline $\begin{array}{c}\text { Passed } \\
\text { sieve no. }\end{array}$ & $\begin{array}{c}\text { Retained } \\
\text { on sieve } \\
\text { no. }\end{array}$ & Percent \\
\hline & 14 & 7.2 \\
8 & 28 & 23.7 \\
14 & 48 & 50.4 \\
48 & 100 & 15.5 \\
100 & $-\ldots .2$ \\
\hline & & 100.0 \\
\hline
\end{tabular}

(b) CEMENTING MATERIALS

There were used 12 masonry cements, two portland cements, and four limes, products of manufacturers in various parts of the United States. These materials are described in table 2. They were received in steel drums and remained in them tightly covered throughout the period of the investigation except at the times that samples were required.

\section{(c) BRICKS}

Six makes of bricks were used and their descriptions are given in table 1.

7 McBain and Ferguson. Jour. Phys. Chem., vol. 31, no. 4, pp. 562-594, 1927.

5 L. A Palmer and D. A. Parsons, The Rate of Stiffening of Mortars on a Porous Base, Rock Products, vol. 35 , no. 18 , pp. 18-24, 1932 .

${ }_{9}$ J. C. Pearson, Properties and Problems of Masonry Cements, Proc. Am. Concrete Inst., vol. 28, p. 349, 1932 . 
TABLE 1

\begin{tabular}{|c|c|c|c|c|}
\hline $\begin{array}{l}\text { Brick } \\
\text { no. }\end{array}$ & Raw materials & Molding process & Rate of absorption & Flat surfaces \\
\hline 1 & Surf & Dry- & Rel & $\mathrm{Me}$ \\
\hline 2 & Sha & $\begin{array}{l}\text { Stiff-mud, end- } \\
\text { cut. }\end{array}$ & $\begin{array}{l}\text { Moderate for shale } \\
\text { bricks. }\end{array}$ & Very rough. \\
\hline 3 & $\ldots d$ & & Relatively slow & Moc \\
\hline 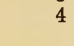 & Surfac & $\begin{array}{l}\text { Soft-mud, sand } \\
\text { struck. }\end{array}$ & Fast, less than no. 1 & Smooth but \\
\hline 5 & Fire clay... & Stiff-mud, side- & Extremely slow_ & Relatively smooth for side \\
\hline 6 & Surface clay & $-\cdots$ & $\begin{array}{l}\text { Fast, less than no. } 1 \text { and } \\
\text { greater than no. } 4 \text {. }\end{array}$ & $\begin{array}{l}\text { Very smooth for side-cut } \\
\text { bricks. }\end{array}$ \\
\hline
\end{tabular}

The rates of absorption of bricks 1 and 5 are generally considered extreme, whereas those of nos. $2,3,4$, and 6 were intermediate. (See fig. 9, p. 629.)

\section{TEST PROCEDURE}

\section{MORTARS}

(a) PROPORTIONING

The method of proportioning the 50 mortars has been presented in a publication (page 18, vol. 35 (18), Rock Products, Sept. 10, 1932), which contains a table descriptive of these mortars. For convenience this table, with the addition of water retaining capacity data from that paper, is given here as table 2.

\section{(b) USE OF THE FLOW TABLE AND SUCTION APPARATUS}

The flow table and its use in making mortar studies has already been described at length. ${ }^{11}$ The Rogers device, used with the flow table in studying the water-retaining capacities of mortars, is illustrated and described on pages 19 and 20 of the Sept. 10, 1932, issue of Rock Products.

\section{TABLE 2.-Mortars studied}

\begin{tabular}{|c|c|c|c|c|c|}
\hline \multirow{2}{*}{$\begin{array}{c}\text { Mortar } \\
\text { desig- } \\
\text { nation }\end{array}$} & \multirow[b]{2}{*}{$\underset{\text { used }}{\text { Cementing materials }}$} & \multirow[b]{2}{*}{$\begin{array}{l}\text { Description of ce- } \\
\text { menting materials }\end{array}$} & \multicolumn{2}{|c|}{ Proportions (with sand) } & \multirow{2}{*}{\begin{tabular}{|} 
Water \\
retaining \\
capacity \\
(flow \\
after 1 \\
minute \\
on \\
standard \\
porous \\
base)
\end{tabular}} \\
\hline & & & $\begin{array}{l}\text { By bulk } \\
\text { volume } 1\end{array}$ & By weight 2 & \\
\hline A I & Portland cement no. 1 . & Gray, typical port- & $1 P C: 3 S$ & $1 \mathrm{PC}: 3.44 \mathrm{~S}_{-.}$ & $\begin{array}{r}\text { Percent } \\
45\end{array}$ \\
\hline 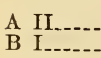 & $\begin{array}{l}\text { Portland cement no. } 2 \\
\text { Masonry cement no. }\end{array}$ & $\begin{array}{l}\text { land. } \\
\text { Mhite- } \\
\text { Modified natural ce- }\end{array}$ & $1 \mathrm{MC}: 3 \mathrm{~S}_{-}$ & $\begin{array}{l}\text { 1PC: } 3.49 \mathrm{~S}_{-.} \\
1 \mathrm{MC}: 4.62 \mathrm{~S} .-\end{array}$ & $\begin{array}{l}47 \\
74\end{array}$ \\
\hline B II..... & & $\begin{array}{l}\text { ment. } \\
\text { Slag and portland }\end{array}$ & & & 65 \\
\hline $\begin{array}{l}\text { B III } \\
\text { B IV..... }\end{array}$ & $\begin{array}{l}\text { Masonry cement no. 3.- } \\
\text { Masonry cement no. } 4 .-\end{array}$ & $\begin{array}{l}\text { Hydraulic lime-... } \\
\text { Slag and hydrated }\end{array}$ & - do do... & $\begin{array}{l}1 \mathrm{MC}: 6.14 \mathrm{~S} \\
1 \mathrm{MC}: 4.48 \mathrm{~S} .-\end{array}$ & $\begin{array}{l}41 \\
48\end{array}$ \\
\hline B V.- & Masonry cement no. 5.. & $\begin{array}{l}\text { lime. } \\
\text { Mixture of hydrated } \\
\text { lime and portland } \\
\text { cement. }\end{array}$ & -.do & $1 \mathrm{MC}: 6.27 \mathrm{~S}$ & 57 \\
\hline B VI... & Masonry cement no. $6^{3}$ & $\begin{array}{l}\text { Modified natural ce- } \\
\text { ment. }\end{array}$ & ..... do & $1 \mathrm{MC}: 5.09 \mathrm{~S}_{-.}$ & 61 \\
\hline
\end{tabular}

1 Dry rodded volumes of sand and of the dry cementing materials. For the lime putties the volumes are of the putties as used.

2 The weight proportions are based on the dry weights of sand and of the dry cementing materials. For mortars containing lime putty the weight proportion of the lime is based on the dry weight of the putty after drying for 24 hours at $115 \mathrm{C}$.

3 Contained metallic stearates.

10 See footnote 8.

11 Volume changes in brick masonry materials, B.S. Jour. Research, vol. 6 (RP 321), p. 1003, 1931. 
TABLE 2.-Mortars studied-Continued

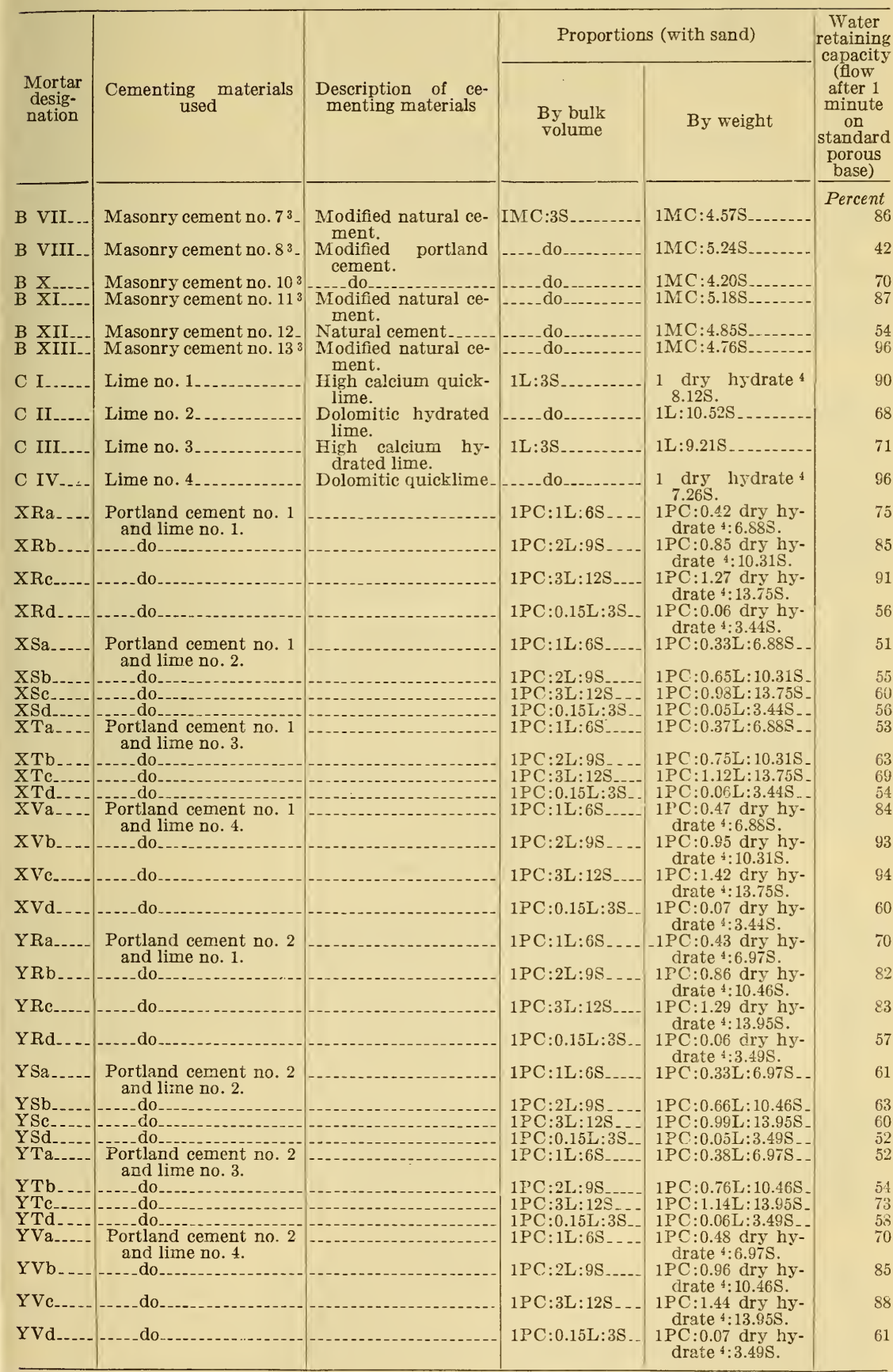

3 Contained metallic stearates.

4 The amount of dry hydrate per unit weight of freshly slaked lime putty was obtained by drying small samples of the putty for 24 hours in an oven at about $115 \mathrm{C}$.

$49727-34-7$ 
A mortar of flow between 75 and 85 percent was considered as being of dry consistency. A mortar of intermediate consistency had a flow between 100 and 110 percent and wet consistency refers to mortar of flow ranging from 125 to 135 percent.

\section{(c) MOLDING OF TEST SPECIMENS}

The compression test specimens were 2-inch cubes. The method of filling the metal molds was that given in Tentative Specifications and Tests for Masonry Cements, A.S.T.M., Tentative Standards, part I, vol. 32,1932 , page 695 .

The method of molding the 1 by 1 by 10 inch bars in the study of shrinkage during early hardening and of the 1 by 4 by 12 inch specimens in the study of later volume changes, sorption, and moduli of rupture and elasticity has already been described. ${ }^{12}$

\section{(d) CLASSIFICATION OF TEST SPECIMENS}

There were 2 series of strength tests made with the 2 -inch cubes. The tests with 1 series were made at the end of 3 months, and those of the other series at the end of a year. There were 9 cubes ( 3 of each consistency, dry, intermediate, and wet) for each mortar in each of the 2 series, a total number of 900 cubes for the 50 mortars, 450 for each test series.

Tests for sorption and volume changes subsequent to hardening were made only with 1 by 4 by 12 inch slab specimens of the series that were kept for a year and tested for transverse strength and modulus of elasticity at the end of that time. Tests for transverse strength and modulus of elasticity at 3 months were made with the other (3 months) series. There were 900 slab specimens, 450 for each series.

For each test for shrinkage during hardening there were three 1 by 1 by 10 inch specimens of each mortar of each consistency, a total of 450 specimens for the 50 mortars.

\section{(e) CURING OF SPECIMENS}

All specimens were made and kept for 1 week in a constant-temperature constant-humidity room (relative humidity, $60 \pm 5$ percent and temperature $70 \pm 2^{\circ} \mathrm{F}$ ). All specimens except the 1 by 1 by 10 inch bars were then kept for 3 weeks in a room of high (95 percent or more) relative humidity, the temperature of which was $70 \pm 4^{\circ} \mathrm{F}$. They were then dried in the laboratory for 2 months. The specimens of the 3-month series were then tested and those of the other series were alternately stored for 1 month in the high-humidity room and for 3 months in the laboratory until they were a year old.

The laboratory temperature ranged from 56 to $94 \mathrm{~F}$, the average being about $68 \mathrm{~F}$. The relative humidity varied from 20 to 85 percent, but usually was within the limits, 30 to 50 percent.

\section{(f) METHODS OF TEST}

The equipment used for determining transverse strength and modulus of elasticity and the method of computing data are presented in Bureau of Standards Research Paper 477, pages 384 to 389.

Compression tests were made in accordance with Federal Specification SS-C-181. Par. F-3-g-6.

\footnotetext{
12 See footnote 11.
} 
The method of measuring linear changes, both those attending early hardening and those produced subsequent to hardening by alternate wetting and drying, has already been described. ${ }^{13}$ Sorption during 15 minutes and 2 hours was obtained by immersing completely in water the slab specimens of the year series at the ages of 3 and 11 months.

\section{BRICKS}

\section{(a) PREPARATION FOR TESTS}

Before being tested, all bricks were dried in an oven $\left(115^{\circ}\right.$ to $\left.150^{\circ} \mathrm{C}\right)$ to constant weight.

The method of determining the rate of absorption with 15 representative bricks of each make is described fully under "Method of Procedure" in Bureau of Standards Research Paper 88, p. 118.

The transverse and compressive strengths, obtained with 25 specimens of each make of brick, were determined in accordance with standard A.S.T.M. specifications. ${ }^{14}$

The method of measuring "moisture expansion" produced by prolonged wetting was the same as that used previously. ${ }^{15}$

The rates of absorption of bricks nos. 1, 2, 4, and 6 following total immersion for 15 minutes in water were also determined. The method was the same as that used in the case of dry bricks.

\section{BRICK-MORTAR SPECIMENS}

(a) PREPARATION OF MATERIALS

Bricks 1, 2, 4, and 6 were set under 2 conditions, namely, dry and after having been totally immersed for 15 minutes in water. Bricks 3 and 5 were set dry in all cases.

Only mortars of intermediate consistency (flow of 100 to 110 percent) were used in making the assemblages.

\section{(b) METHOD OF FORMING TEST SPECIMENS}

The mortar joints were approximately $1 / 2$ inch thick. The procedure followed in bedding the bricks in mortar and in placing $3 / 8$ inch brass lugs when used in the joints has been described. ${ }^{16}$

All test specimens were made in the constant temperature-constant humidity room and, except series $5 \mathrm{~A}$ remained there for a week after being made.

\section{(c) CLASSIFICATION OF TESTS}

A classification of the tests is made on the basis of method of exposure, type of specimen, and purpose of the test. There were six methods of exposure, designated as A, B, C, D, E, and F in table 3.

The test specimens are classified and described in table 4.

\section{(d) MEASUREMENTS}

The method of measuring strength of bond is described in detail in a previous publication. ${ }^{17}$

\footnotetext{
13 See footnote 11 .

14 Standard Method of Testing Brick (Compression, Flexure, and Abscrption) (C 67-31), 1933 Book of A.S.T.M. Standards, pt. II, p. 128.

is See footnote 11.

${ }_{10}$ Durability and Strength of Bond Between Mortar and Brick, B.S. Jour. Research, vol. 6 (RP 290), p. 473,1931 .

${ }_{17}$ See footnote 16.
} 
TABLE 3.-Exposure of brick-mortar test specimens

\begin{tabular}{|c|c|c|}
\hline $\begin{array}{l}\text { Exposure designa- } \\
\text { tion }\end{array}$ & $\begin{array}{l}\text { Aging } \\
\text { period }\end{array}$ & Description \\
\hline & Months $_{3}$ & ant-humidity room, ${ }^{1}$ then 3 \\
\hline & & $\begin{array}{l}\text { weeks in high-humidity (relative humidity } 95 \text { percent or more) room, } \\
\text { followed by } 2 \text { months in the laboratory. }\end{array}$ \\
\hline & 12 & $\begin{array}{l}\text { Exposure during first } 3 \text { months, same as A. This was followed by } \\
\text { alternate wetting for } 1 \text { month in the high-humidity room, and drying } \\
\text { for } 3 \text { months in the laboratory. }\end{array}$ \\
\hline & 12 & $\begin{array}{l}\text { First week in constant-temperature constant-humidity room, }{ }^{1} \text { followed } \\
\text { by aiternate drying for } 18 \text { days in the high-temperature low-humidity } \\
\text { room, }{ }^{2} \text { then wetting for } 8 \text { days by partial immersion, again drying, } \\
\text { wetting, etc., until specimens were } 1 \text { year old. }\end{array}$ \\
\hline & ${ }^{3} 18$ & $\begin{array}{l}\text { First year, same as C. This was followed by } 5 \text { cycles of alternate } \\
\text { freazing and thawing (see footnote } 17 \text {, then dried for } 18 \text { days in the } \\
\text { high-temperature low-humidity room, } 2 \text { followed by freezing and } \\
\text { thawing (see footnote 17), drying, etc., until specimens had under- } \\
\text { gone a total of } 35 \text { freezings and thawings. }\end{array}$ \\
\hline & 3 & $\begin{array}{l}\text { First week in high-temperature low-humidity room, }{ }^{2} \text { then } 3 \text { weeks in } \\
\text { high-humidity room followed by } 2 \text { months in laboratory. }\end{array}$ \\
\hline$F_{-}$ & 37 & $\begin{array}{l}\text { First } 4 \text { weeks same as A. Then } 18 \text { days in high-temperature low- } \\
\text { humidity room followed by alternate freezing and thawing ( } 5 \text { cycles), } \\
\text { drying for } 18 \text { days etc. as in } D \text {. After } 35 \text { freezings and thawings (see } \\
\text { footnote } 17 \text { ), specimens were dried in high-temperature low-humidity } \\
\text { room }{ }^{2} \text { for } 18 \text { days. }\end{array}$ \\
\hline
\end{tabular}

1 Temperature, $70 \pm 2^{\circ}$ F., relative humidity, $60 \pm 5$ percent.

2 Temperature, $120 \pm 5^{\circ} \mathrm{F}$., relative humidity, 20 to 30 percent.

3 Approximate. 


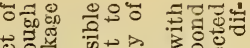

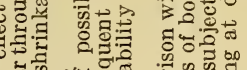

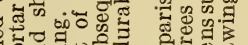

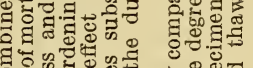

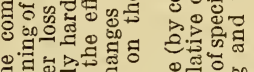

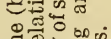

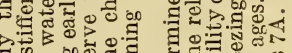

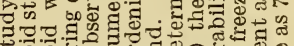

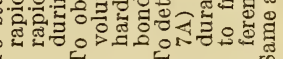

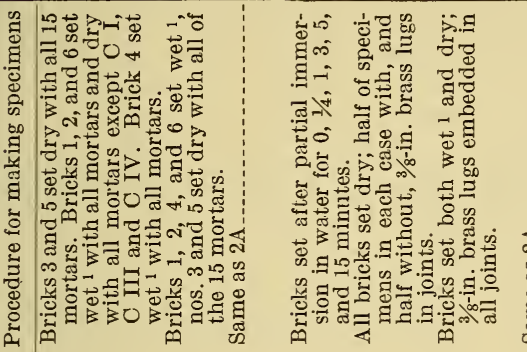

$$
\text { F H D }
$$

\begin{tabular}{|c|c|c|c|c|c|c|c|c|c|c|}
\hline 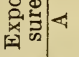 & $m$ & 0 & G & 69 & 4 & $A$ & $E$ & A & $\triangleleft$ & 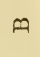 \\
\hline
\end{tabular}

\begin{tabular}{|c|c|c|c|}
\hline 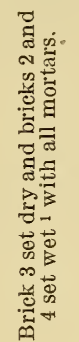 & 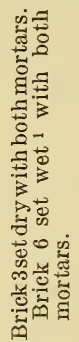 & 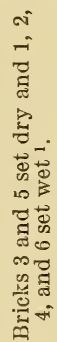 & 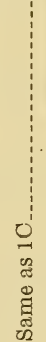 \\
\hline
\end{tabular}

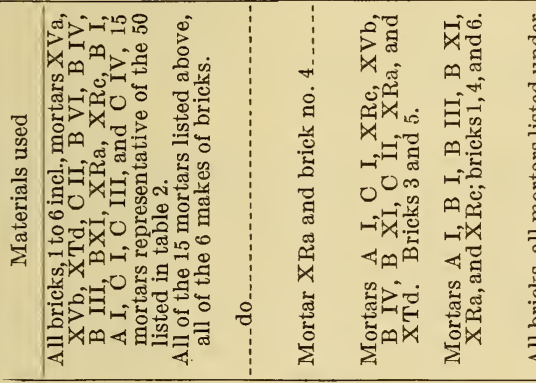

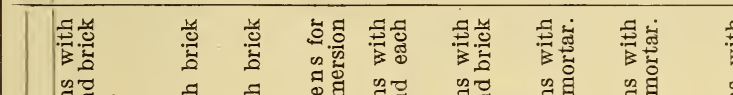

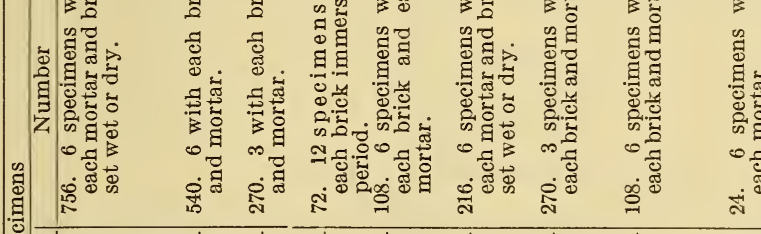

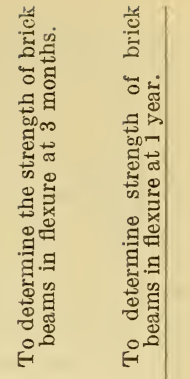


Durability of bond was studied by cyclic wetting, freezing and thawing and drying. Wetting by partial immersion for 48 hours preceded each group of 5 freezing and thawing cycles. The saturated specimens, partially immersed, remained for 18 hours in a freezing chamber after which they were kept under water at room temperature for 6 hours and thus thawed. The freezing temperature varied from about $12^{\circ}$ to $30^{\circ} \mathrm{F}$., being usually within the limits, $15^{\circ}$ to $24^{\circ} \mathrm{F}$. The specimens were dried for 18 days in the high-temperature low-humidity room (see footnote, table 3 ) after each 5 cycles of freezing and thawing. Specimens were subjected to a total of 35 freezing and thawing cycles with 6 intervening drying periods and another following the completion of the 35 cycles. It was considered that the bond had failed, when on lifting the specimen by the top brick, the lower one dropped off.

The equipment for measuring the transverse strength of brick beams (series $1 \mathrm{C}$ and $2 \mathrm{C}$, table 4 ) was the same as that used for determining the transverse strength of brick. ${ }^{18}$ The span in this case, however, was 11 inches, approximately the distance from the midpoints of the edges (faces) of the two bricks at opposite ends of the 5-brick 4-joint beams. The total overhang was thus the weight of 1 brick and this was taken as the mean of 25 separate weighings of individual bricks (dry) of each make. The load was applied at the middle of the beam.

The modulus of rupture (lb per sq in.) was computed from the formula:

$$
\mathrm{MR}=\frac{3}{b d^{2}}\{x[P+p(1-x / 11)]\}
$$

in which: $P$ is the applied load, pounds, $p$ is the weight of the beam, minus the weight of the overhang, $b$ and $d$ are the width and depth (inches), respectively, of the beam at the section of failure, and $x$ denotes the distance of this section from the nearer support.

Usually failure was at one of the two joints adhering to the middle brick, and 3-brick piers (2 intervening joints) were taken from the broken beams for compression tests, performed according to the procedure followed in testing half bricks. ${ }^{19}$

\section{RESULTS}

\section{MORTARS}

\section{(a) WATER-RETAINING CAPACITY}

As a brief résumé of the results of tests for water-retaining capacities of mortars already published ${ }^{20}$ it may be said that the slaked lime putty and stearated masonry cement mortars (made from the natural cements) were found to be the most retentive of water of all of the 50 mortars according to the method of test. The partial substitution of the slaked lime putties for the two portland cements produced a considerable increase in water-retaining capacity above that of the straight portland cement mortars which were among the lowest with respect to this property. The presoaked hydrated limes had much

18 See footnote 14.

19 See footnote 14 .

20 See footnote 8. 
the same effect as the slaked lime putties but to a much less extent. The water-retaining capacity of hydrated lime mortars was improved by soaking the limes for 24 hours before mixing.

\section{(b) SHRINKAGE DURING EARLY HARDENING}

The results are given in table 5. For the portland-cement-lime mixtures the averages are of all of the combinations of the 2 portland cements and 4 limes for each definite proportion by volume. This averaging of all brands for the portland-cement-lime mixtures explains the magnitude of the deviations from the mean as shown by the maximum and minimum values, in comparison with the deviations for the individual brands of lime and portland cement.

TABLE 5.-Linear shrinkage during early hardening of 1 by 1 by 10 inch mortar specimens

[Averages are of 24 specimens in the case of lime-portland-cement mixtures and of 3 specimens for all other mortars. Maximum and minimum values for the lime-portland-cement mixtures are averages of 3 specimens!

\begin{tabular}{|c|c|c|c|c|c|}
\hline \multirow{2}{*}{$\begin{array}{l}\text { Mortar com- } \\
\text { position }\end{array}$} & \multirow{2}{*}{ Cementing materials } & \multirow{2}{*}{$\begin{array}{c}\text { Mortar } \\
\text { designa- } \\
\text { tion }\end{array}$} & \multicolumn{3}{|c|}{ Linear shrinkage during initial 48 hours at 3 consistencies } \\
\hline & & & Dry & Intermediate & Wet \\
\hline $1 \mathrm{PC}: 1 \mathrm{~L}: 6 \mathrm{~S}$ & $\begin{array}{l}\text { All combinations of } \\
2 \text { portland cements } \\
\text { and } 4 \text { limes. }\end{array}$ & & $\begin{array}{ll} & \text { Percent } \\
\text { avg } & 0.28 \\
\max & .35 \text { (YTa) } \\
\min & .23 \text { (XVa) }\end{array}$ & $\begin{array}{ll} & \text { Percent } \\
\text { avg } & 0.30 \\
\max & .35(\mathrm{XTa}) \\
\min & .26(\mathrm{YVa})\end{array}$ & \begin{tabular}{ll}
\multicolumn{3}{c}{ Percent } \\
avg & 0.33 \\
$\max$ & $.39(\mathrm{XRa})$ \\
$\min$ & $.23(\mathrm{Y} \mathrm{Va})$
\end{tabular} \\
\hline $1 \mathrm{PC}: 2 \mathrm{~L}: 9 \mathrm{~S}$. & -..--do_. & & $\begin{array}{ll}\operatorname{avg} & .40 \\
\max & .45 \\
\min & .34 \text { (YTh) } \\
\text { (XRb) }\end{array}$ & $\begin{array}{ll}\text { avg } & .48 \\
\max & .61(\text { YTb }) \\
\min & .41(\mathrm{XRb})\end{array}$ & $\begin{array}{ll}\text { avg } & .51 \\
\max & .64(\mathrm{YRb}) \\
\min & .47(\mathrm{XRb})\end{array}$ \\
\hline $1 \mathrm{PC}: 3 \mathrm{~L}: 12 \mathrm{~S}$ & ......do_. & & $\begin{array}{lll}\operatorname{avg} & .48 & \\
\max & .54 & (\mathrm{XRc}) \\
\min & .41 & (\mathrm{YSc})\end{array}$ & $\begin{array}{lll}\operatorname{avg} & .62 & \\
\max & .77 & (\mathrm{YRc}) \\
\min & .52 & (\mathrm{YSc})\end{array}$ & $\begin{array}{lll}\operatorname{avg} & .67 & \\
\max & .84 & \text { (YRc) } \\
\min & .53 & \text { (YTc) }\end{array}$ \\
\hline $1 \mathrm{PC}: 0.15 \mathrm{~L}: 3 \mathrm{~S}$ & -.-.-do_ & & $\begin{array}{ll}\operatorname{avg} & .21 \\
\max & .25 \\
\min & .14(\mathrm{XTd}) \\
(\mathrm{X} \vee \mathrm{d})\end{array}$ & $\begin{array}{ll}\operatorname{avg} & .24 \\
\max & .30(\mathrm{XTd}) \\
\min & .18(\mathrm{XVd})\end{array}$ & $\begin{array}{ll}\operatorname{avg} & .25 \\
\max & .32(\mathrm{XTd}) \\
\min & .20(\mathrm{X} V \mathrm{~d})\end{array}$ \\
\hline $\begin{array}{r}\text { 1PC:3S } \\
\text { Do }\end{array}$ & $\begin{array}{l}\text { PC no. } 1 . . \\
\text { PC no. } 2 . .\end{array}$ & $\begin{array}{l}\text { A I } \\
\text { A II }\end{array}$ & $\begin{array}{l}\text { Avg percent } \\
.13 \\
.18\end{array}$ & $\begin{array}{l}\text { Avg percent } \\
\quad .21 \\
\quad .24\end{array}$ & $\begin{array}{l}\text { Avg percent } \\
\quad .24 \\
.31\end{array}$ \\
\hline $\begin{array}{r}\text { 1L:3S } \\
\text { Do } \\
\text { Do Do } \\
\text { Do }\end{array}$ & $\begin{array}{l}\text { Lime no. } 1 \\
\text { Lime no. } 2 \\
\text { Lime no. } 3 \\
\text { Lime no. } 4\end{array}$ & $\begin{array}{l}\text { C I } \\
\text { C II } \\
\text { C III } \\
\text { C IV }\end{array}$ & $\begin{array}{l}.94 \\
.57 \\
.68 \\
.59\end{array}$ & $\begin{array}{r}1.11 \\
.66 \\
.75 \\
. .81\end{array}$ & $\begin{array}{r}11.35 \\
.72 \\
.83 \\
1.94\end{array}$ \\
\hline 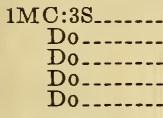 & $\begin{array}{l}\text { MC no. } 1 \\
\text { MC no. } 2 \\
\text { MC no. } 3 \\
\text { MC no. } 4 \\
\text { MC no. } 5\end{array}$ & $\begin{array}{l}\text { B I } \\
\text { B II } \\
\text { B III } \\
\text { B IV } \\
\text { B V }\end{array}$ & $\begin{array}{l}.29 \\
.29 \\
.28 \\
.21 \\
.33\end{array}$ & $\begin{array}{l}.37 \\
.31 \\
.32 \\
.24 \\
.34\end{array}$ & $\begin{array}{l}.46 \\
.36 \\
.37 \\
.29 \\
.39\end{array}$ \\
\hline 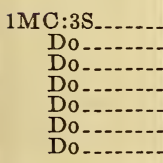 & 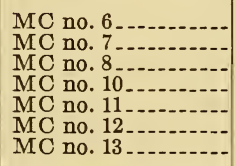 & $\begin{array}{l}\text { B VI } \\
\text { B VII } \\
\text { B VIII } \\
\text { B X } \\
\text { B XI } \\
\text { B XII } \\
\text { B XIII }\end{array}$ & $\begin{array}{l}.32 \\
.24 \\
.35 \\
.33 \\
.25 \\
.40 \\
.46\end{array}$ & $\begin{array}{l}.36 \\
.32 \\
.36 \\
.32 \\
.28 \\
.52 \\
.58\end{array}$ & $\begin{array}{l}.46 \\
.42 \\
.48 \\
.36 \\
.36 \\
.60 \\
.62\end{array}$ \\
\hline
\end{tabular}

1 Specimens measured when a week old. Too soft to measure at 48 hours.

The averages of table 5 are highest for the straight lime-sand and $1 \mathrm{PC}: 3 \mathrm{~L}: 12 \mathrm{~S}$ mortars and lowest for the straight portland-cementsand mortars. The magnitude of linear shrinkage during the initial 48 hours of the $1 \mathrm{PC}: 1 \mathrm{~L}: 6 \mathrm{~S}$ and the $1 \mathrm{PC}: 2 \mathrm{~L}: 9 \mathrm{~S}$ mortars ranged from a low average, 0.28 percent (average, dry consistency, all $1 \mathrm{PC}: 1 \mathrm{~L}: 6 \mathrm{~S}$ 
mortars) to a high average of 0.51 percent (average all $1 \mathrm{PC}: 2 \mathrm{~L}: 9 \mathrm{~S}$ mortars of wet consistency). These values fall within the range of the 12 different masonry cement mortars $(0.21$ percent, $\mathrm{MC}$ no. 4, average for dry consistency, to 0.62 percent, $\mathrm{MC}$ no. 13 , average for wet consistency).

\section{(c) VOLUME CHANGES SUBSEQUENT TO HARDENING}

Typical data are presented in figures 1 and 2. Initial strain-gage readings were taken when specimens were a week old. Expansion

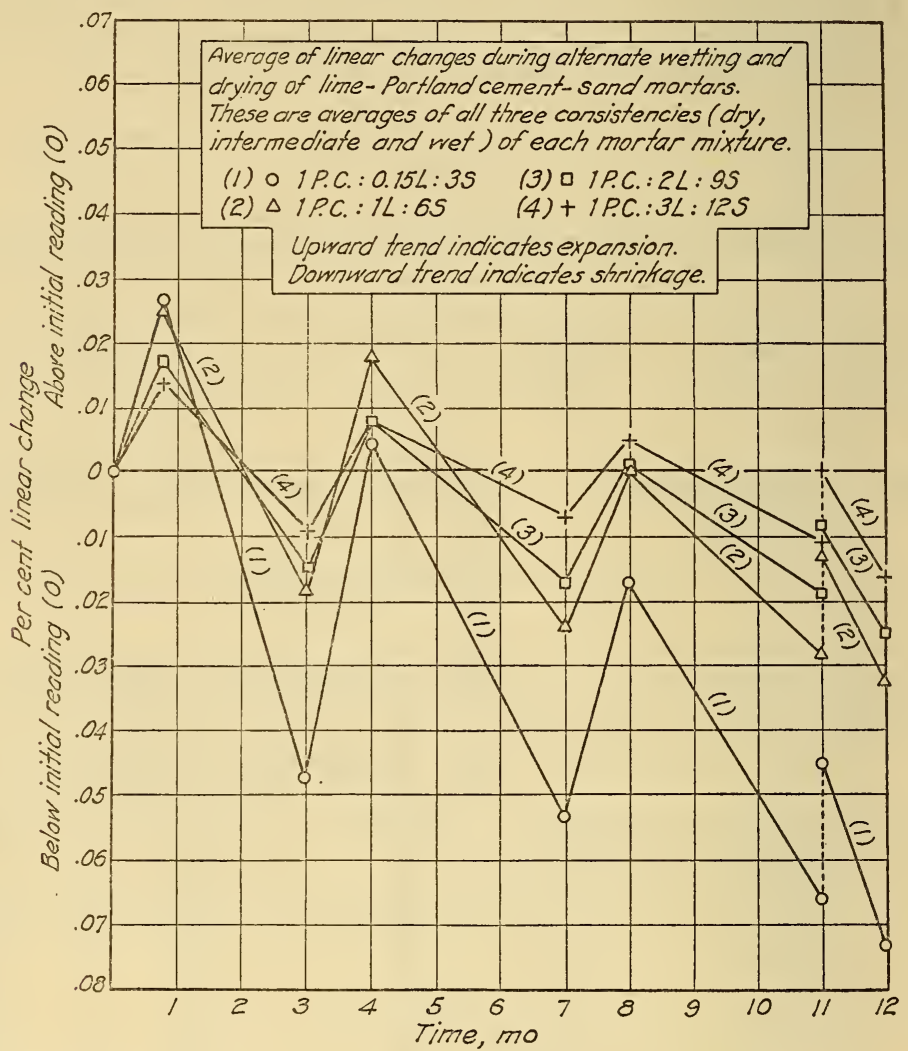

Figure 1.-Typical linear changes in lime-portland-cement mortar specimens subsequent to hardening.

and shrinkage during subsequent wetting and drying periods were computed with reference to these initial readings. Since only changes in length (not absolute lengths) were measured, the initial points are taken as the origin (specimens 1 week old).

Each plotted point of figure 1 is an average of all three consistencies (dry, intermediate, and wet) and all brands of the materials (lime and portland cement) are included in each proportion by volume as indicated. Each plotted value is, therefore, the average of 72 measurements (3 specimens, 3 consistencies, 8 mortars).

Wach plotted point of figure 2 is an average of 9 measurements, 3 specimens with each consistency with each mortar. Masonry cement 
mortar B III had the lowest, and B XI the highest volume changes of the 12 masonry cement mortars. The averages of the other 9 masonry cement mortars would, if plotted in figure 2 , either coincide with or fall between the plotted values.

The plotted data indicate the extent of variation in linear changes of mortars of different compositions. The highest linear changes were obtained with masonry cement mortar B XI and the lowest with lime mortar C III. Values for the lime mortars were all relatively very low, checking previously published results. ${ }^{21}$ Linear changes of the individual $1 \mathrm{PC}: 0.15 \mathrm{~L}: 3 \mathrm{~S}$ mortar mixtures were in all cases slightly higher than corresponding values obtained with the $1 \mathrm{PC}: 3 \mathrm{~S}$ mortars.

The specimens were subjected relatively more to drying than to wetting, the object being to roughly parallel average climatic conditions. Figures 1 and 2 show relatively more shrinkage than expansion

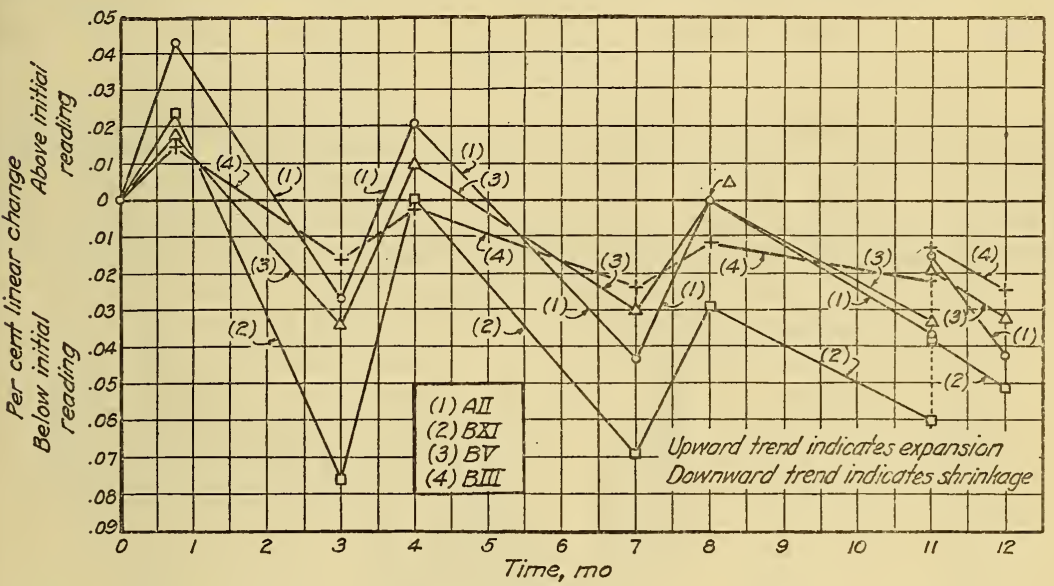

FIGURE 2.-Typical linear changes in masonry and portland cement mortars subsequent to hardening.

over the course of a year, possibly due to the preponderance of drying.

It may be noted (figs. 1 and 2) that the greatest shrinkage for all mortars occurred during the first drying period. Of the masonry and straight portland-cement mortars, this shrinkage was greatest for specimens of wet consistency for all mortars except A I, B II, B VI, B IV, and B V, being greatest with dry consistency with mortars A I, B VI, and B II, greatest with intermediate consistency in the case of $\mathrm{B} \mathrm{V}$, and there was the same average value with both consistencies, wet and dry, in the case of B IV. The greatest variation with consistency was had with mortar B XII, the average shrinkage being $0.020,0.034$, and 0.041 percent for specimens of dry, intermediate, and wet consistencies, respectively, during the first drying period. The corresponding values in the case of mortar A I in which shrinkage varied least with consistency were $0.061,0.061$, and 0.064 percent, respectively. Thus there was a maximum variation of 100 percent and a minimum of 5 percent between the different consistencies in this group of mortars.

\footnotetext{
${ }^{21}$ See reference, footnote 11.
} 
In the case of straight lime-sand mortars this variation was relatively high (50 to 300 percent) as would be expected since both the shrinkage and expansion subsequent to hardening in these mortars was relatively very low. The variation in shrinkage with consistency among the portland-cement-lime mortar mixtures was usually less

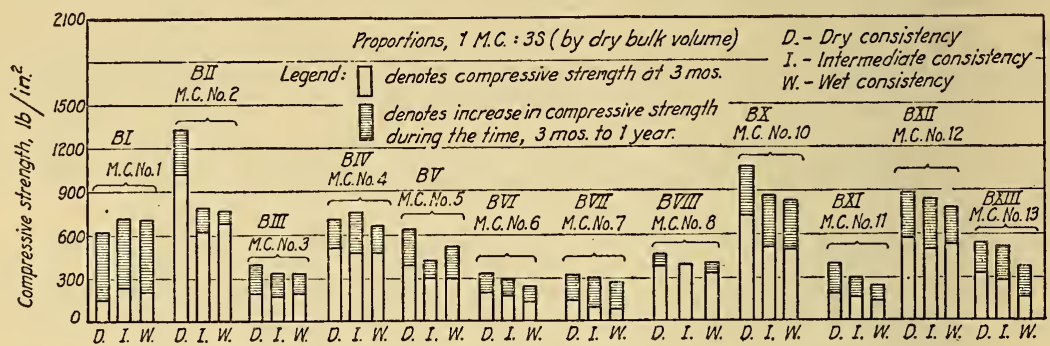

FIGURE 3.-Average compressive strengths of 2-inch mortar cubes at 3 months and 1 year.

than that characteristic of the masonry cement and straight portlandcement mortars, ranging from 3 (mortar XTd) to 53 (mortar YRc) percent. For all but 12 (XRd, XSc, XTb, XRc, XVc, XVd, YSa, YTd, YRa, YRc, YVb, and YVd) of the 32 portland-cement-lime mixture mortars, the linear shrinkage during the first drying period

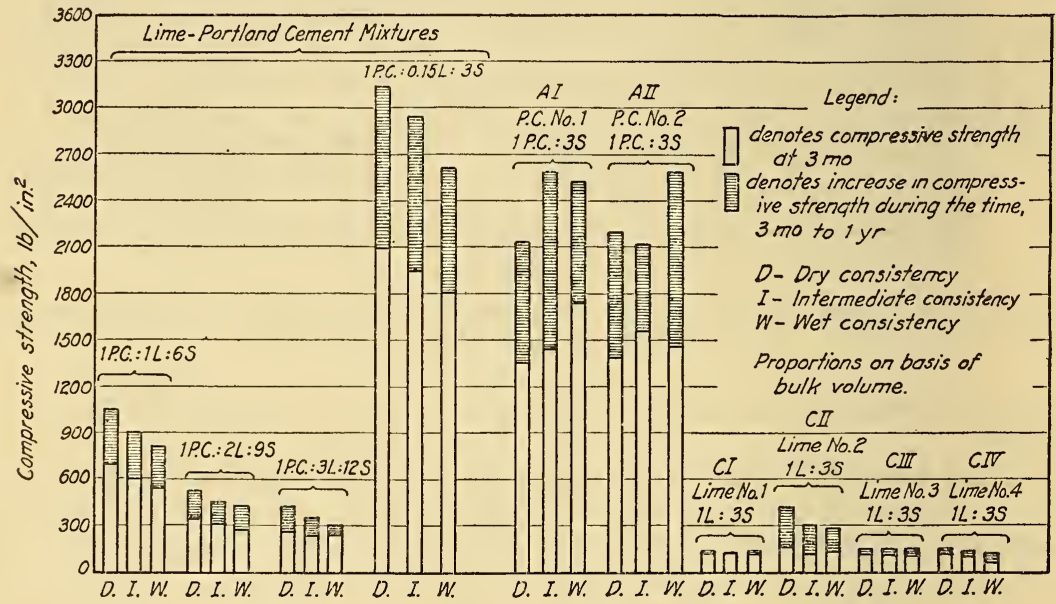

FigURE 4.-Average compressive strengths of 2 -inch mortar cubes at 3 months and 1 year.

was greater for wet than for dry consistency. The values for 11 of these 12 exceptions (excluding YRc) indicate relatively small variation with consistency.

In the three specimens of any mortar (exclusive of straight lime-sand mortars) of a given consistency, the maximum deviation from the mean value ranged from 6 to 24 percent, being greatest in the case of those mortars undergoing relatively small changes in length. 
(d) COMPRESSIVE AND TRANSVERSE STRENGTH

Compressive and transverse strengths are plotted in figures 3,4 , 5 , and 6 . In figures 3 and 5 the heights of the vertical columns for the portland-cement-lime mixtures are averages for each consistency of the eight different portland-cement-lime combinations in each of the four definite proportions (1PC:1L:6S, 1PC:2L:9S, 1PC:3L:12S, and $1 \mathrm{PC}: 0.15 \mathrm{~L}: 3 \mathrm{~S})$ by volume.

It is not apparent from the graphs that transverse strength could always be accurately predicted from compressive strength, or vice

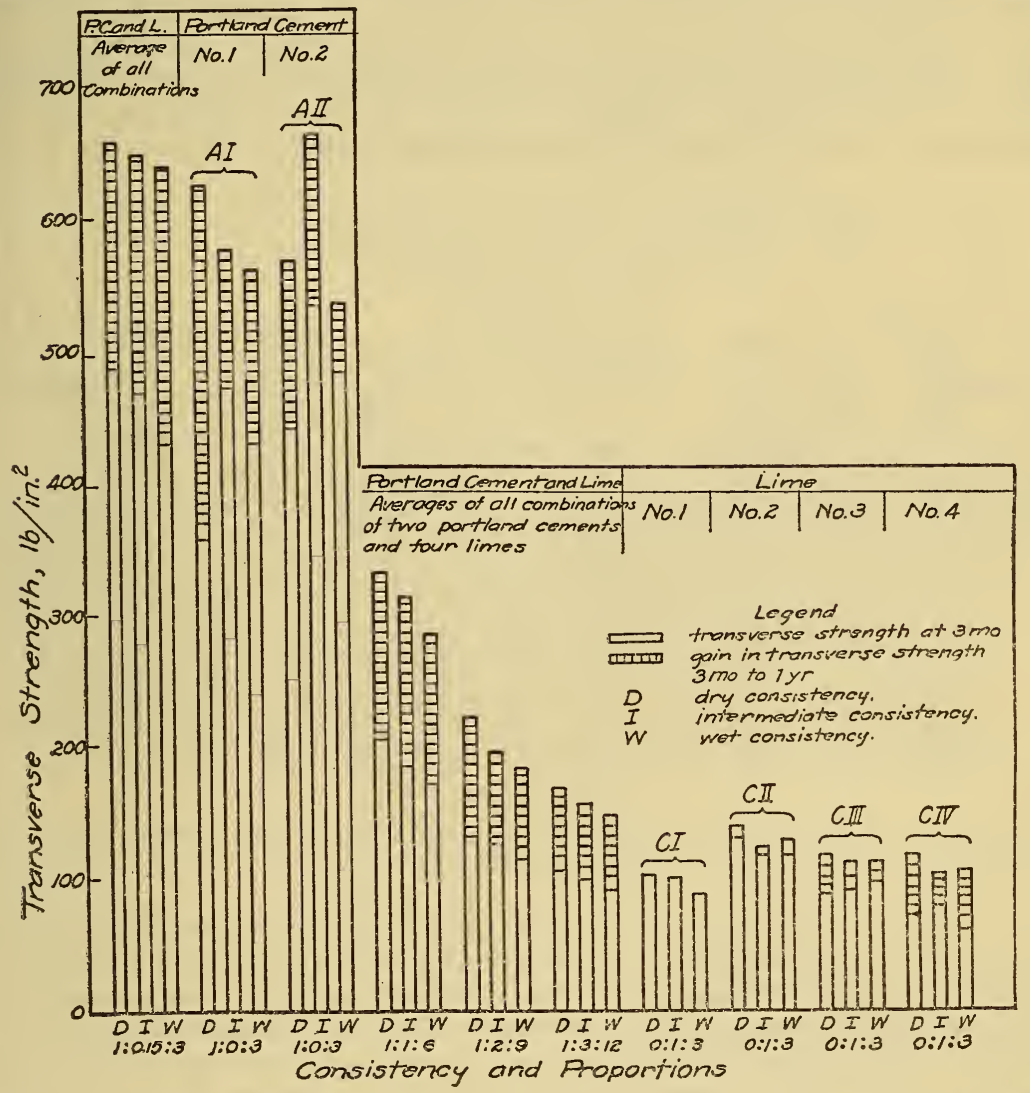

FIGURE 5.-Average transverse strengths of 1 by 4 by 12 inch mortar slabs at 3 months and 1 year.

versa. For example, the masonry cement mortars listed in the order of increasing magnitude of transverse strength at the end of a year (considering all consistencies) are as follows: B XI, B VII, B VI, B V, B IV, B VIII, B XIII, B III, B I, B II (B II same strength at 1 year as at 3 months), B XII, and B X. Listing these same mortars similarly on the basis of compressive strength at a year, the order is: B VI, B VII, B XI, B III, B VIII, B XIII, B V, B I, B IV, B XII, $\mathrm{B} X$, and $\mathrm{B}$ II (last two nearly equal). The transverse strength test specimens differed materially in size and shape from those used in determining compressive strength. 
It is seen, figures $3,4,5$, and 6 , that higher transverse and compressive strengths were associated with drier consistencies, two notable exceptions being portland cement mortars A I and A II which were very low in water retaining capacity. During the first week in the constant temperature room, from visual inspection, specimens of these mortars apparently dried more quickly than specimens of mortars of higher water-retaining capacity. Specimens of mortars of A I and A II of wet consistency retained more moisture during the week's initial drying than those of dry consistency, there being more water initially present in the former case. Hence, it may be concluded that there was a greater degree of early hydration in mortars A I and A II, of wet consistency than was the case when the initial consistency was dry. This may have more than compensated for the fact that ordinarily in wet storage, portland cement mortar specimens of dry consistency would naturally have a higher density (less void space)

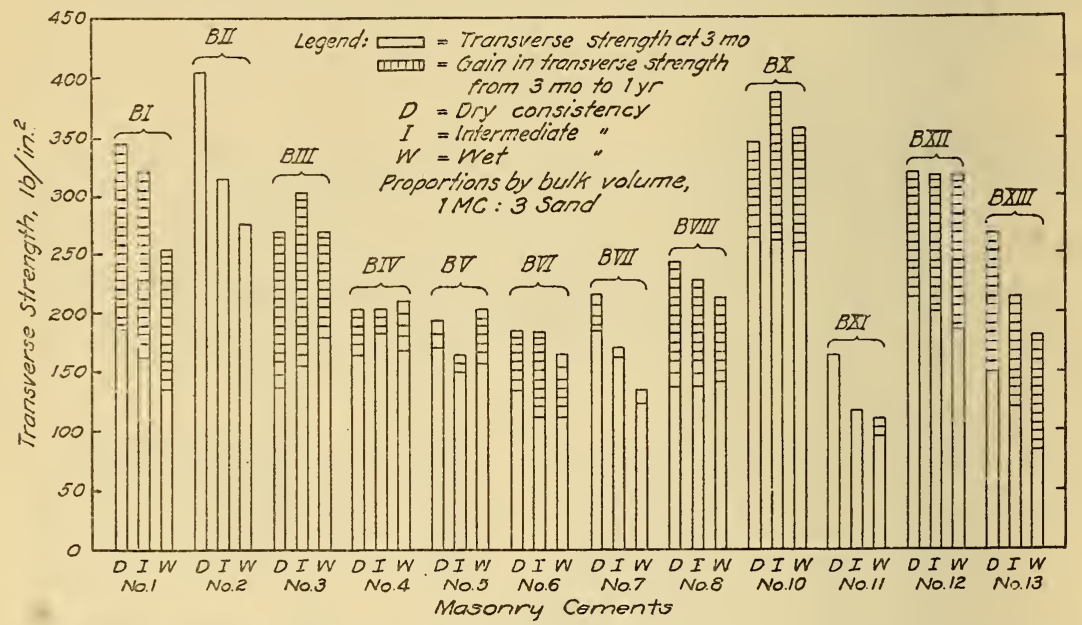

FIGURE 6.--Average transverse strengths of 1 by 4 by 12 inch mortar slabs at 3 months and 1 year.

and hence greater strength on that account than specimens from mortars of wet consistency. In this connection note that the strength, compressive and transverse, was highest for dry consistency in portland-cement-lime mortar mixtures. It has already been shown ${ }^{22}$ that the substitution of lime for portland cement decreases the water loss by suction. It is probable that water loss through capillary movement and surface evaporation during a few days subsequent to the removal of the cubes from the molds is similarly reduced.

The plotted data of figures 3 to 6 , inclusive, show that both the compressive and transverse strength of the mortars which were richer in portland cement than the 1:1:6 mix, were greater than that of the others. The average strength, either compressive or transverse, of the $1 \mathrm{PC}: 1 \mathrm{~L}: 6 \mathrm{~S}$ mortar mixtures was equal to or greater than that of the strongest of the 12 masonry cement mortars, B II, B X, and $\mathrm{B}$ XII, and that of the 1PC:2L:9S mortar mixtures compared favorably with 6 of the masonry cement mortars, B III, B IV, B VII, B VIII, B XI, and B XIII. Moreover, the compressive strengths of 
both 3 months and year old specimens of the straight lime mortar, C II (lime no. 2), compared favorably with corresponding values obtained with masonry cement mortars B XI, D VII, B VI, and B IIl. The 1:3 lime mortars, C I, C III, and CIV, were weaker than any of the other mortars.

The strength of a portland-cement-lime mixture mortar was not determined by the strength of either of the two mortars containing only portiand cement or only lime, with sand. 'This is evident from the data of table 6 and figure 3. Possibly the density of the portlandcement-lime mixture, as infiuenced by its grading, was the most important factor.

TABLE 6.-Maximum and minimum compressive and transverse strengths of limeportland, cement mortar mixtures at 3 months and 1 year

[Values are averages for 3 specimens]

[D denotes dry, I intermediate, and W wet consistency]

\begin{tabular}{|c|c|c|c|c|}
\hline \multirow{3}{*}{ Mortar mixture } & \multicolumn{4}{|c|}{ Compressive strength } \\
\hline & \multicolumn{2}{|c|}{3 months } & \multicolumn{2}{|c|}{1 year } \\
\hline & Maximum & Minimum & Maximum & Minimum \\
\hline $\begin{array}{l}\text { 1PC:1L:6S } \\
\text { 1PC:2L:9S } \\
1 \mathrm{PC}: 3 \mathrm{~L}: 12 \mathrm{~S} \\
1 \mathrm{PC}: 0.15 \mathrm{~L}: 3 \mathrm{~S}\end{array}$ & $\begin{array}{r}\text { Lb/in. } .^{2} \\
888 \text { (XVa-D) } \\
459 \text { (XVb-D) } \\
455 \text { (XVc-D) } \\
2,833 \text { (XVd-D) }\end{array}$ & $\begin{array}{c}\text { Lb/in.2 } \\
410(\mathrm{XRa-W}) \\
169(\mathrm{XRb}-\mathrm{W}) \\
134(\mathrm{XRc}-\mathrm{W}) \\
1,081(\mathrm{XRd}-\mathrm{I})\end{array}$ & $\begin{array}{c}\text { Lb/in. } .^{2} \\
1,136(X V \mathrm{a}-\mathrm{D}) \\
750 \text { Ysb-W) } \\
620(\mathrm{YVc}-\mathrm{D}) \\
3,755\left(\mathrm{YSd}^{\mathrm{Y} S \mathrm{D})}\right.\end{array}$ & $\begin{aligned} & \text { Lb/in. } .^{2} \\
448 & (\mathrm{XRa}-W) \\
302 & (\mathrm{XRb}-\mathrm{I}) \\
203 & (\mathrm{XRc}-W) \\
1,216 & (\mathrm{XRd}-W)\end{aligned}$ \\
\hline \multirow{3}{*}{ Mortar mixture } & \multicolumn{4}{|c|}{ Transverse strength (modulus of rupture) } \\
\hline & \multicolumn{2}{|c|}{3 months } & \multicolumn{2}{|c|}{1 year } \\
\hline & Maximum & Minimum & Maximum & Minimum \\
\hline $\begin{array}{l}\text { 1PC:1L:6S } \\
1 \mathrm{PC}: 2 \mathrm{~L}: 9 \mathrm{~S}^{-} \\
1 \mathrm{PC}: 3 \mathrm{~L}: 12 \mathrm{~S} \\
1 \mathrm{PC}: 0.15 \mathrm{~L}: 3 \mathrm{~S}\end{array}$ & $\begin{array}{l}\text { Lb/in. } \\
282 \text { (XTa-D) } \\
153 \text { (XTb-D) } \\
136 \text { (XSc-D) } \\
692 \text { (XTd-D) }\end{array}$ & 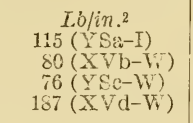 & 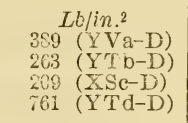 & $\begin{aligned} & \text { lb/in.2 } \\
178 & \text { (XRa-W) } \\
138 & \text { (YVb-W) } \\
97 & (\text { Y Rc-W) } \\
367 & \text { (XVd-W) }\end{aligned}$ \\
\hline
\end{tabular}

Of the portland-cement-lime mortar nixtures, the greatest variation in compressive strength with consistency in any mortar was 82 percent (mortar XVc) and the least was 3 percent (mortar YTc). The density of specimens of mortar XVc varied with consistency to a much greater extent than was the case with mortar Y Y $\mathrm{T}$. With the portand and masonry cement mortars the corresponding figures are 74 percent (B II) and 11 percent (B XII). In transverse strength neasurements, the corresponding variations were 70 percent $(\mathrm{XVd}$ ) and 5 percent (YTb) in the case of portland-cement-lime mortar mixtures and 63 percent (BII) and 2 percent (B XII) among the portland and masonry cement mortars.

The percentage variations in results obtained with individual mortars of the same consistency were higher generally in the case of compressive strength test data (2 to 41 percent nt 3 months and 2 to 28 percent at 1 year) than was the case in tests for transverse strength 
(4 to 32 percent at 3 months and 1 to 24 percent at 1 year). Excluding the straight lime-sand mortars, the weakest masonry cement mortars and the 1PC:3L:12S mortar mixtures, the variations among individual specimens of a kind seldom exceeded 10 percent in either transverse or compressive strength tests.

\section{(e) MODULUS OF ELASTICITY AND EXTENSIBILITY}

The extensibility of a mortar specimen is the amount per unit of length that the specimen will elongate before rupturing in tension. For the present purpose, extensibility is considered as obtained by dividing the modulus of rupture (MR) by the modulus of elasticity (ME), and the result is expressed as inches per 100,000 inches.

A grouping of the elasticity moduli and extensibilities of all mortars determined both at 3 months and 1 year is given in table 7 . The modulus of elasticity varied both with time and consistency as shown in this table. For example, mortar XTd of intermediate consistency when made, had a modulus in the $2,000,000$ to $2,250,000$ group at 3 months and was in the highest $(5,000,000$ to $5,500,000)$ group at 1 year.

TABLE 7.-Moduli of elasticity and extensibility of mortars at 3 months and 1 year

[Each number in the second column is the average of 3 tests]

Legend: 3 -month-old specimens $\left\{\begin{array}{l}\text { d, dry consistency } \\ \text { i, intermediate consistency } \\ \text { w, wet consistency }\end{array}\right.$
1-year-old specimens $\left\{\begin{array}{l}\text { D, dry consistency } \\ \text { I, intermediate consistency } \\ \text { W, wet consistency }\end{array}\right.$

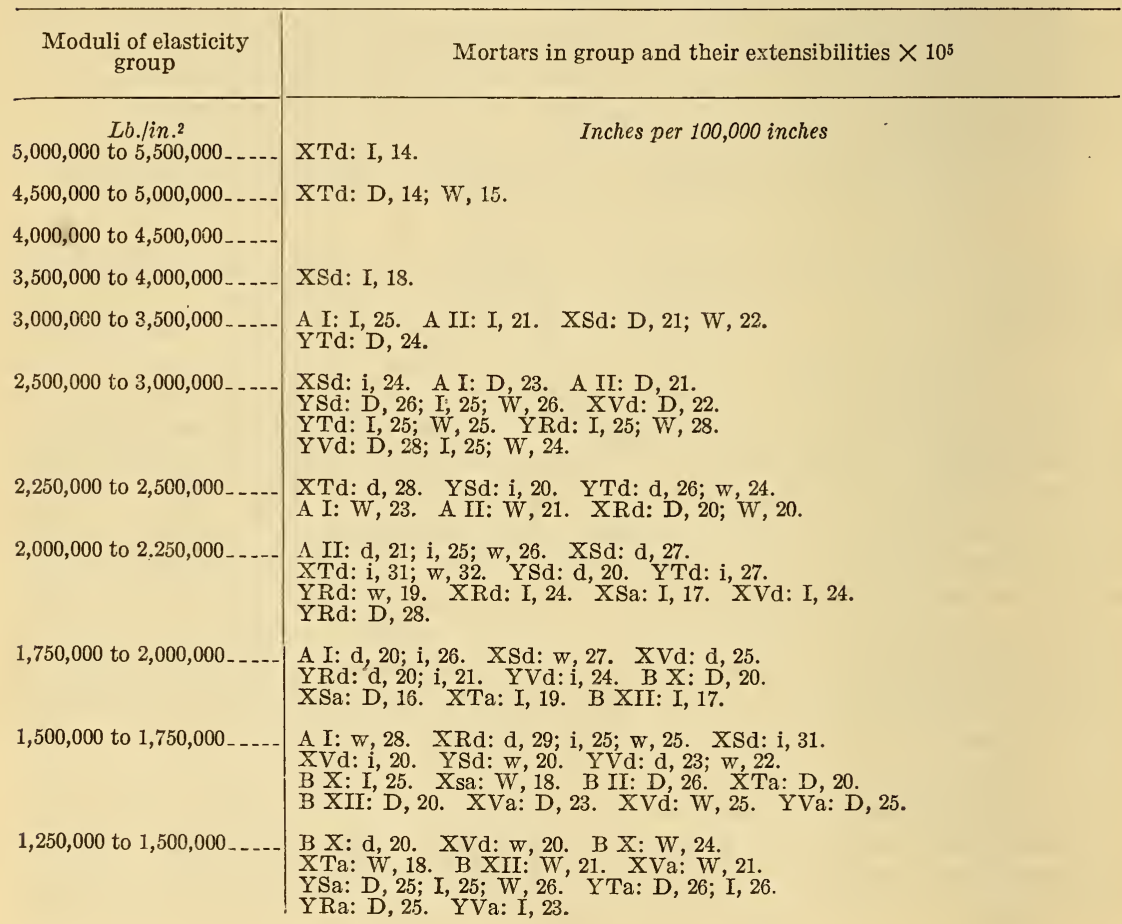


TABLE 7.-Moduli of elasticity and extensibility of mortars at 3 months and 1 yearContinued

\begin{tabular}{|c|c|}
\hline $\begin{array}{l}\text { Moduli of elasticity } \\
\text { group }\end{array}$ & Mortars in group and their extensibilities $\times 10^{5}$ \\
\hline $\begin{array}{l}\text { Lb./in. }{ }^{2} \\
1,000,000 \text { to } 1,250,000 \ldots\end{array}$ & $\begin{array}{l}\text { Inches per } 100,000 \text { inches } \\
\text { B X: i, 25; w, 20. XSa: d, 23; i, 23. } \\
\text { B II: d, 35. XTa: d, 26; i, 22. YTa: d, } 20 . \\
\text { YRa: d, } 21 . \text { B III: D, 27; I, 28. } \\
\text { XRa: D, 22; I, 19. B VI: D, 16. } \\
\text { B I: D, 25; I, 28. XSb: D, 22. B II: I, } 28 . \\
\text { XSc: D, 20. B XIII: D, 25. B IV: D, 20. } \\
\text { B VIII: D, 23. XTb: D, 19. B V: D, 19. } \\
\text { XVa: I, 25. XVb: D, 22; I, 21. XVc: D, 19. } \\
\text { YSb: D, 25. YTa: WV, 28. YTb: D, 23; I, } 25 . \\
\text { YRa: I, 28. YVa: W, 29. }\end{array}$ \\
\hline 900,000 to $1,000,000 \ldots$ & $\begin{array}{l}\text { B III: w, 19. B I: d, 21; w, } 14 . \\
\text { B II: i, 35; w, 31. B XII: d, 24; i, } 25 . \\
\text { YTa: W, 19. B III: W, 30. B VII: D, } 22 . \\
\text { XRa: W, 20. B II: W, 26. B XIII: I, } 23 . \\
\text { B IV: D, 21; I, 22. B VIII: I, 24. B V: W, } 22 . \\
\text { XVb: W, 24. Ysb: I, 25. Y Ra: W, } 29 .\end{array}$ \\
\hline 800,000 to 900,000 & $\begin{array}{l}\text { B III: d, 17. XSa: W, 25. XTa: w, 28. } \\
\text { YTa: } 1,20 . \text { YRa: i, 23. B VI: I, 20; W, } 21 . \\
\text { B I: W, 30. XRb: D, 22; W, 23. XSb: I, } 20 . \\
\text { XSc: I, 22. B XIII: W, 23. B VIII: W, } 25 . \\
\text { B V: I, 20. XRc: D, 21. YSb: W, } 30 \text {. YTb: W, } 29 .\end{array}$ \\
\hline 700,000 to $800,000 \ldots$ & $\begin{array}{l}\text { B III: i, 20. B VII: d, 27. B XI: d, } 21 . \\
\text { B I: i, 22. XSb: d, 25. B IV: i, } 26 . \\
\text { B V: d, 24. XVa: d, 26. YRa: W, } 23 . \\
\text { YVa: d, 21; i, 22. B VII: I, 22; W, } 23 . \\
\text { B XI: D, 21. XRb: I, 24. XSb: W, } 25 . \\
\text { XSc: W, } 26 . \text { XTb: I, 22. XTc: D, 23. } \\
\text { XRc: I, 21; W, 18. YSc: I, 26. YTc: I, } 25 . \\
\text { YTc: D, 24; W, 25. YRb: D, 24. YVb: D, } 28 .\end{array}$ \\
\hline 600,000 to $700,000 \ldots$ & 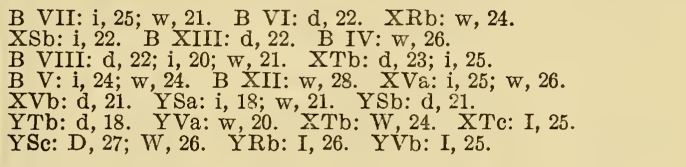 \\
\hline 500,000 to 600,000 & $\begin{array}{l}\text { B XI: i, 21. XRa: d, 29; w, 24. B VI: i, } 22 . \\
\text { XRb: d, 26. XSb: w, 25. XSc: d, 27. } \\
\text { B IV: d, 29. XTb: w, 25. XVc: d, 22. } \\
\text { YSa: d, 20. YSb: i, 22. YTb: i, 21; W, } 21 . \\
\text { YVb: d, 21. YVc: d, 21. B XI: I, 23. } \\
\text { C II: D, 27; W, 25. C III: D, 21; W, 18. } \\
\text { XTc: W, 26. C IV: D, 22; I, 19. YRb: W, } 35 . \\
\text { YRc: D, 23; I, 20. YVb: W, 28. }\end{array}$ \\
\hline 450,000 to 500,000 & $\begin{array}{l}\text { B XI: w, 20. XRa: i, 28. B VI: w, } 22 . \\
\text { C II: d, 28. XRb: i, 30. B XII: i, } 24 . \\
\text { XVb: i, 24. YSb: w, 25. YRb: d, 20. } \\
\text { YVb: i, 21. C II: I, 27. C III: I, 24. } \\
\text { C IV: W, 21. YVe: D, 22. }\end{array}$ \\
\hline 400,000 to 450,000 & $\begin{array}{l}\text { C II: i, 28; w, 26. XSc: i, } 29 . \\
\text { C III: i, 22; W, 22. XTc: d, 23; i, 24; w, } 19 . \\
\text { XRc: i, 25. XVc: i, 24. YSc: d, 20. } \\
\text { YTc: d, 25; i, 24; W, 24. YRb: i, 24; w, } 26 . \\
\text { YRc: W, } 24 . \text { B XI: W, } 26 . \text { C I: I, } 27 . \\
\text { YRc: W, } 22 .\end{array}$ \\
\hline 350,000 to $400,000 \ldots$ & $\begin{array}{l}\text { XSc: w, 28. B XIII: w, 23. C III: d, } 24 . \\
\text { XRc: d, 25; w, 25. XVb: w, 21. XVc: w, } 25 . \\
\text { YRc: d, } 25 ; \text { i, } 24 . \text { YVb: w, 25. YVc: i, } 24 .\end{array}$ \\
\hline 300,000 to $350,000 \ldots$ & $\begin{array}{l}\text { C I: d, 34; i, 31; w, } 27 . \text { C IV: i, } 25 . \\
\text { YSc: i, } 26 ; \text { w, } 22 .{ }_{\text {YVc: }} \text { w, } 24 . \text { C I: D, } 29 . \\
\text { YVc: I, } 32 ; \text { W, } 34 .\end{array}$ \\
\hline 250,000 to 300,000 & C IV: d, 25. C I: W, 27 \\
\hline 200,000 to $250,000 \ldots$ & C IV: $w, 26$ \\
\hline
\end{tabular}


The extensibilities of all 50 mortars varied from a minimum of 14 inches per 100,000 inches (XTd intermediate consistency, at 3 months) to a maximum of 35 inches per 100,000 inches (B II, dry consistency, at 3 months). The majority of the values were within the limits,

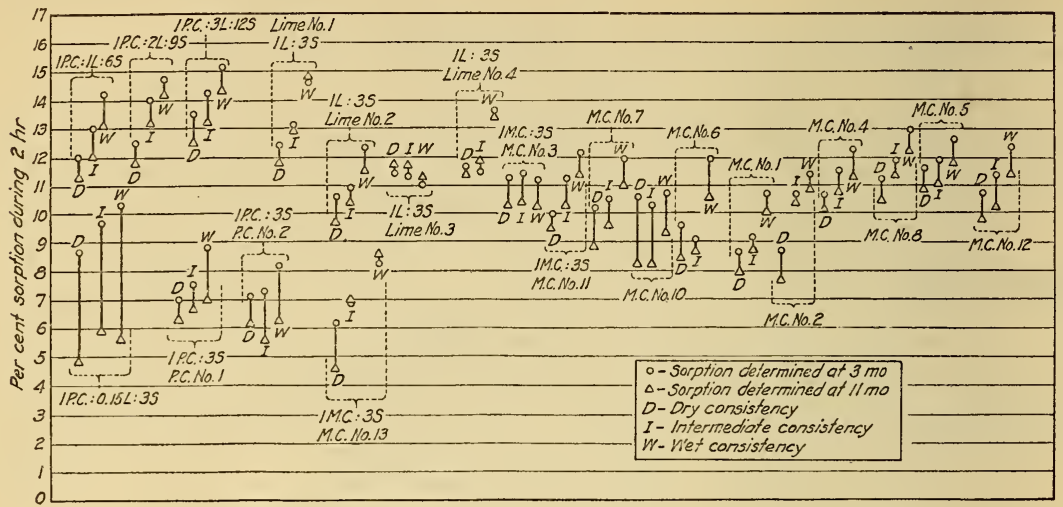

FIGURE 7.-Average percent sorption of mortar slabs at 3 and 11 months.

20 to 25 inches per 100,000 inches. There was a slight tendency for the extensibility to increase as the modulus of elasticity decreased and vice versa, but there are many exceptions.

In most cases the moduli of elasticity increased with time. This increase was usually greater than the corresponding increase in

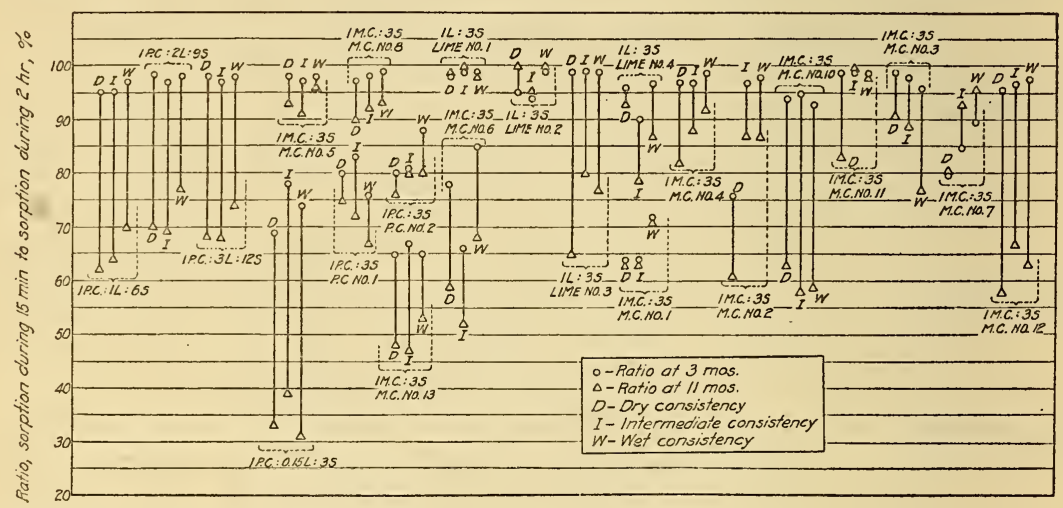

FIGURE 8.-Average ratios, sorption during 15 minutes to 2 hours obtained with mortar slabs at 3 and 11 months.

modulus of rupture, hence the extensibility tended usually to decrease with time.

(f) SORPTION

The sorption data are illustrated in figures 7 and 8 . After total immersion for 15 minutes, the specimens were weighed and returned to water where they remained for an additional $1 \frac{13}{4}$ hours when they were again weighed. The ratios, sorption at 15 minutes to that at 2 hours, are plotted in figure 8. 
In figure 7 it is seen that in many instances there was an appreciable decrease in sorption (at the end of 2 hours total immersion) at 11 months over that shown at 3 months. Also, the change (increase or decrease) in percent sorption over this period of time was relatively very small in the case of the straight lime-sand mortars. An interesting fact in this connection is that any appreciable decrease in percent sorption during this period was attended by an increase in dry weight (drying in the air of the laboratory). White ${ }^{23}$ has made similar observations and discussed them at length.

Each plotted point (figs. 7 and 8) for each of the 4 lime-portlandcement mixtures (1PC:1L:6S, 1PC:2L:9S, 1PC:3L:12S and $1 \mathrm{PC}: 0.15 \mathrm{~L}: 3 \mathrm{~S}$ ) is the average of all of the 8 different mortars of the same consistency and of the same mixture. It is important to note that the average sorptions during 2 hours (fig. 7) of the mortar mixtures, $1 \mathrm{PC}: 1 \mathrm{~L}: 6 \mathrm{~S}, 1 \mathrm{PC}: 2 \mathrm{~L}: 9 \mathrm{~S}$ and $1 \mathrm{PC}: 3 \mathrm{~L}: 12 \mathrm{~S}$, exceeded the average sorptions both of the individual straight lime-sand mortars and the portland-cement-sand mortars. Furthermore, the decrease in sorption over the period, 3 to 11 months, of the 1PC:0.15L:3S mortar mixtures was greater than that of any other mortar. The mortars having lowest sorptions were the $1 \mathrm{PC}: 0.15 \mathrm{~L}: 3 \mathrm{~S}$, $1 \mathrm{MC}: 3 \mathrm{~S}$ (MC no. 13), and the two straight 1PC:3S mortars.

If the ratio, sorption at 15 minutes to sorption at 2 hours (fig. 8), is nearly unity, then the amount of sorbed water increased relatively

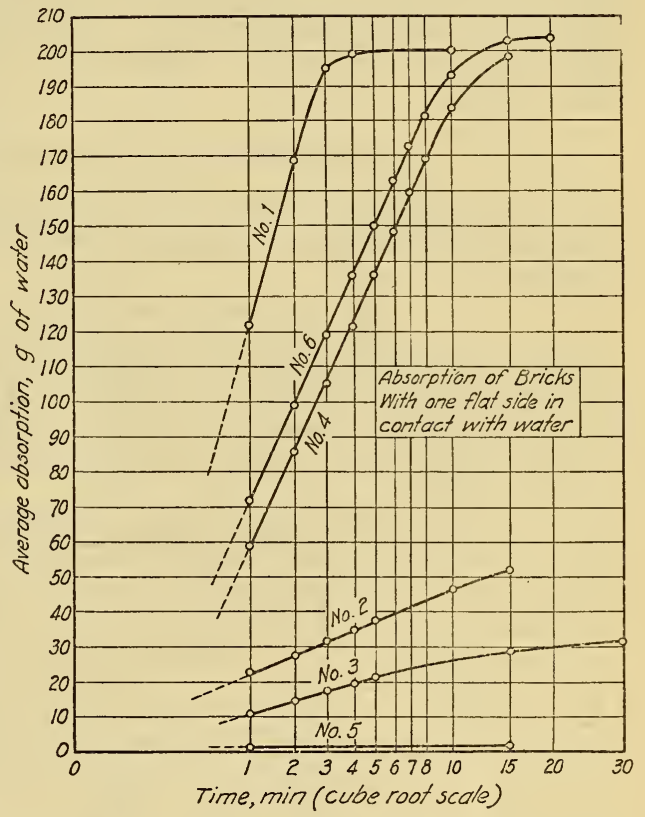

FIgURE 9.-Average rates of absorption of bricks by partial immersion. slowly with time after the initial 15-minute period of immersion. These ratios decreased with time (3 to 11 months) in practically all cases, the decrease being greatest in the $1 \mathrm{PC}: 0.15 \mathrm{~L}: 3 \mathrm{~S}$ mortar mixture and nearly zero in other cases (lime-sand mortars, limes nos. 1 and 2 and $\mathrm{MC}$ no. 1 ).

The variations in measurements made with the same mortar and the same consistency ranged from 2 to 24 percent, usually not exceeding 12 percent of the mean value.

\section{BRICKS}

\section{(a) ABSORPTION RATES}

Each plotted point of figure 9 is the average number of grams of water per brick absorbed through the flat side areas of 15 specimens of any one make of brick during 1,2, 3, etc., minute intervals. The

${ }^{23}$ A. H. White, The use of lime in stuccos, Proc. National Lime Association, 1916, p. 109. $49727-34-8$ 
average areas of the exposed flat sides of each of the 6 makes of brick were all very nearly equal to $30 \mathrm{sq}$ in $(193.5 \mathrm{sq} \mathrm{cm})$. It is seen in figure 9 that with this average amount (grams) of water plotted against the cube root of the corresponding time interval, the points are on straight lines in all cases throughout a certain interval of time, corresponding to the time required for the particular type of brick to wet through from bottom to top, the water rising by capillarity. This linear relationship between the quantity of water absorbed by partial immersion and the cube root of the corresponding time interval, is in agreement with results previously published..$^{24}$

The rate of absorption of brick no. 5 was extremely slow (fig. 9).

The values at 1 minute (fig. 9 ) were used in subsequent calculations. Total immersion for 15 minutes greatly reduced the absorption by partial immersion for 1 minute. For bricks 1, 2, 4, and 6 these values were $3.2,2.1,3.3$, and 3.8 grams of water per 30 square inches, respectively.

\section{(b) COMPRESSIVE AND TRANSVERSE STRENGTH}

The average compressive and transverse strengths and the individual maximum and minimum values of the 6 bricks are given in table 8.

\section{(c) EXPANSION OF BRICKS ON WETTING}

The 5 specimens with each make of brick (3 bricks each, joined end to end) ${ }^{25}$ tended generally to expand slowly during prolonged immersion (1 month) in water, but only to a slight extent in any case. This is in good agreement with the data of others. ${ }^{26}$

TABLE 8.-Compressive and transverse strengths of bricks

[Each average value was obtained with 25 specimens]

\begin{tabular}{|c|c|c|c|c|c|c|}
\hline \multirow{2}{*}{ Brick no. } & \multicolumn{3}{|c|}{ Compressive strength } & \multicolumn{3}{|c|}{ Modulus of rupture } \\
\hline & A verage & $\begin{array}{l}\text { Individual } \\
\text { maximum }\end{array}$ & $\begin{array}{l}\text { Individual } \\
\text { minimum }\end{array}$ & Average & $\begin{array}{l}\text { Individual } \\
\text { maximum }\end{array}$ & $\begin{array}{l}\text { Individual } \\
\text { minimum }\end{array}$ \\
\hline 1 & $\begin{array}{r}L b / i n .^{2} \\
7,435 \\
6,705 \\
14,750 \\
4,330 \\
16,025 \\
4,830\end{array}$ & $\begin{array}{r}L b / i n .2 \\
8,790 \\
8,480 \\
18,670 \\
6,080 \\
21,170 \\
7,230\end{array}$ & $\begin{array}{r}L b / i n .2 \\
6,000 \\
4,450 \\
11,150 \\
3,000 \\
13,220 \\
3,650\end{array}$ & $\begin{array}{r}\text { Lb/in. } .^{2} \\
764 \\
2,090 \\
1,800 \\
529 \\
2,665 \\
609\end{array}$ & $\begin{array}{r}\text { Lb/in. } .^{2} \\
880 \\
2,870 \\
3,310 \\
710 \\
3,340 \\
886\end{array}$ & $\begin{array}{r}\text { Lb/in. }{ }^{2} \\
575 \\
1,090 \\
1,210 \\
305 \\
1,670 \\
424\end{array}$ \\
\hline
\end{tabular}

The linear expansions of the brick specimens during one month in water were $4,3,3,4,0$, and 4 thousandths of a percent for bricks nos. 1 to 6 , respectively.

\section{ASSEMBLAGES}

(a) STRENGTH OF BOND

(1) General Considerations. All of the data obtained with test series $1 \mathrm{~A}$ to $6 \mathrm{~A}$ (table 4), inclusive, are plotted in figures 10 and 11 . The length of the vertical line connecting all of the points for any one

${ }^{24}$ L. A. Palmer, Some absorption properties of clay bricks, B.S. Jour. Research, vol. 3 (RP88), p. $105,1929$.

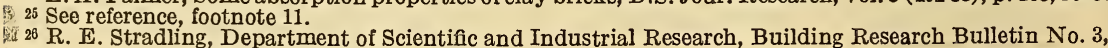
Effect of moisture changes on building materials. 
mortar, is an indication of the variability in strength of bond obtained under different conditions. The mortars with which strength of

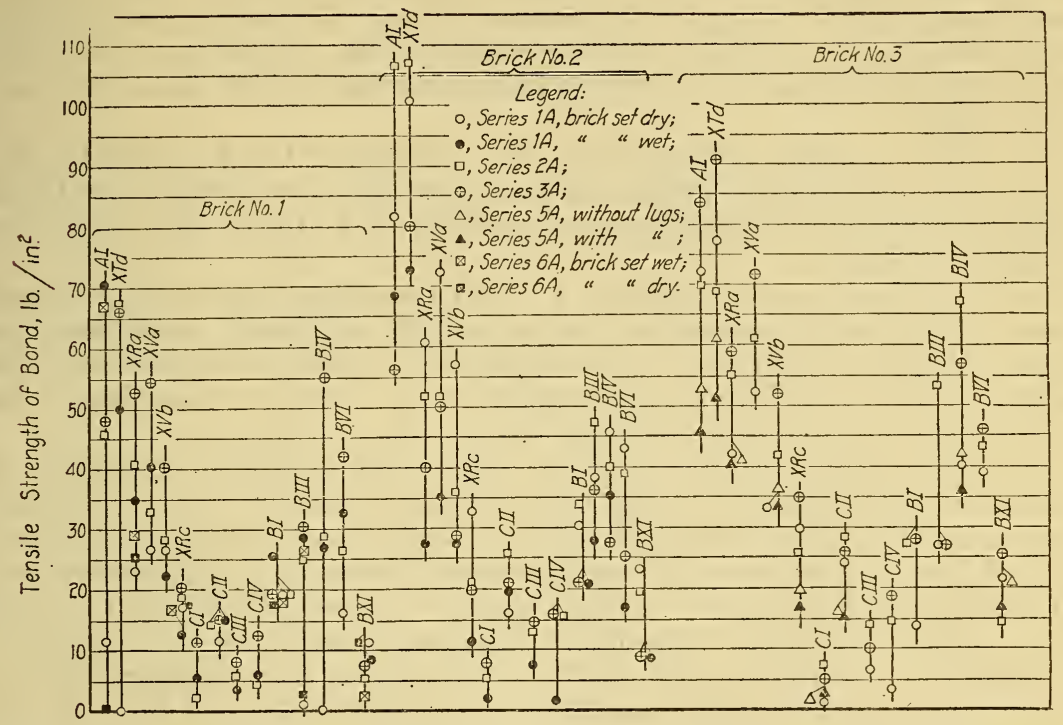

FigURE 10.-Average bond strengths in tension obtained with two brick-mortar specimens.

bond varied least with the conditions were those which had the least variation in extent of bond ${ }^{27}$ with the types of bricks included in this

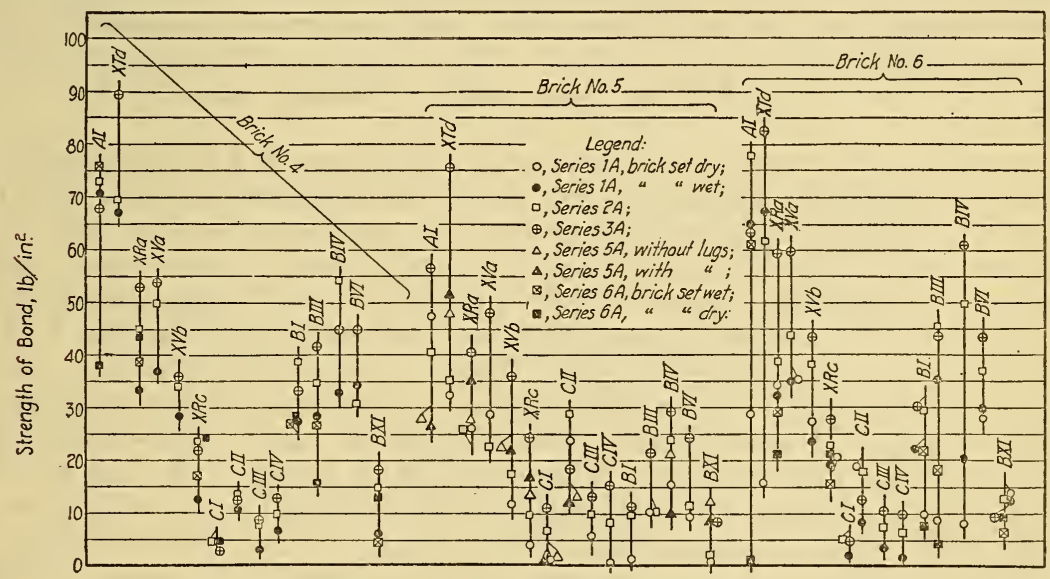

Figure 11.-Average bond strengths in tension obtained with two brick-mortar specimens.

study. The important consideration is the minimum value obtained with any one mortar and type of brick. For example, the minimum value is zero, with brick no. 1 and mortar XTd (fig. 10) and this was

27 The fraction or percent of the total flatside area of a brick to which mortar adehres. Extent of bond may be considered as the bonded area and in this investigation it was estimated from visual inspection of broken specimens. 
not due to total lack of strength in this mortar but to poor ${ }^{28}$ extent of bond, and the minimum values (figs. 10 and 11) are indicative of the poorest extent of bond when the relatively strong mortars are considered. It is evident from figures 10 and 11 that the strength of bond varied over a wider range generally with certain mortars (A I and XTd, for example) than with other mortars (XVb, XRc, B I and B VI, etc.).

It is also equally evident that the maximum bond strengths obtained with all mortars and brick no. 2 tended to be higher than bond strengths obtained with the same mortars and any of the other five makes of bricks.

It may, therefore, be said that a type of building unit may be found that is relatively adaptable under widely different conditions to various types of mortars, and conversely, a type of mortar may be selected that is relatively adaptable under varying conditions to widely difierent types of building units.

(2) The effect of brick suction, the water retaining capacity of mortar and strength of mortar on bond strength. The average amounts of water absorbed during the first minute of partial immersion of five of the makes of bricks ranged from 10 to 120 grams per 30 square inches of brick surface (fig. 9). That of brick no. 5 was 1.5 g. The "suction" (amount absorbed during the first minute) was slightly more than $20 \mathrm{~g}$ in the case of brick no. 2. From figures 12 and 13 note that at 3 months, for a brick suction of $20 \mathrm{~g}$, in all cases, the bond strength is very near the maximum value.

The data, plotted in figures 12 and 13, give curves typical of the other mortars. All of the six makes of bricks set dry and nos. 1, 2, 4 , and 6 set wet are represented in figures 12 and 13 . The bricks when set wet (after 15 minutes total immersion) were extremely low in suction. It is seen that the bond strength increased from very low brick suction to the maximum and then decreased, gradually or sharply, depending on the mortar. This steepness of descent of the mortar curves depended on the water-retaining capacity of the mortars.

The descent of the curves for mortars XRc and B I of high waterretaining capacity is gradual and those for mortars A I and B III (figures 12 and 13) descend more abruptly as the maximum point is reached and passed. It is apparent from these curves that the mortars of highest strength and lowest water-retaining capacity (A I and B III) actually gave lower bond strength with bricks 1, 4, and 6 set dry than mortars XRc, XRa, B I, and B XI, which were weaker in strength but much higher in water-retaining capacity than mortars A I and B III. The mortars of high water-retaining capacity were more resistant to the suction of bricks 1, 4, and 6 set dry and as a consequence produced greater extent of bond with these bricks than was obtained with the mortars of low water-retaining: capacity, A I and B III. The poor extent of bond with mortars A I and B III with the porous bricks accounts for their lower bond strength.

From the standpoint of bond strength, brick no. 2 having a rate of absorption less than that of no. 4 (intermediate, see fig. 9) was better

\footnotetext{
${ }_{2 \S}$ If the extent of bond was less than 90 percent, it was called poor. Good (practically complete) extent of bond was from 95 to 100 percent. With but very few exceptions the bond was either good or considerably luss than 90 percent.
} 
suited to all of the types of mortars studied than any of the other bricks.

The initial steep ascents of all of the curves (figs. 12 and 13) is of interest. Despite the shapes of these curves, there is apparently no

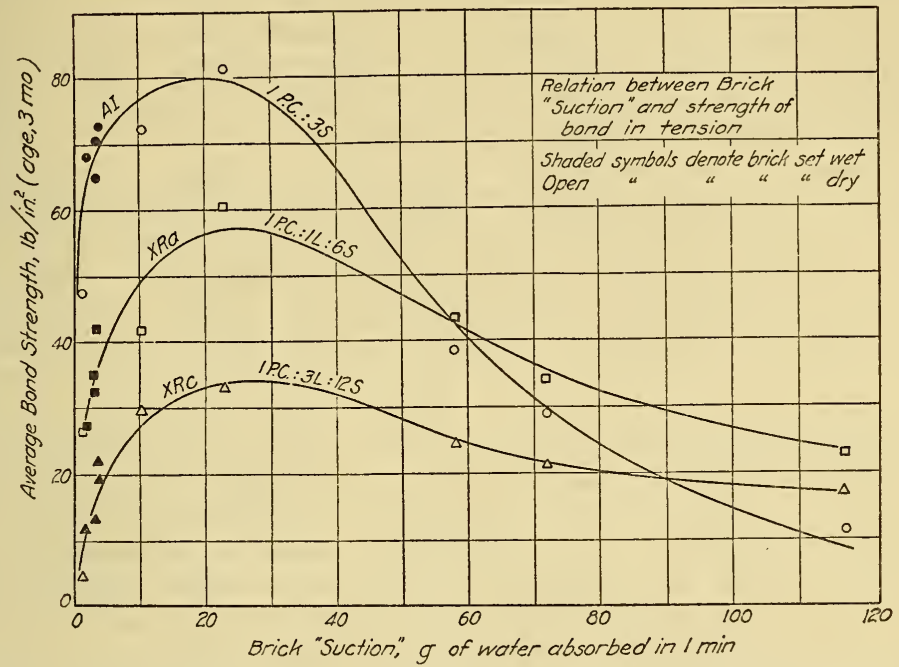

FIGURE 12.-Bond strength as related to brick suction and water-retaining capacity of morlars.

justification for extrapolation to zero; it is known that mortars adhere to glass bricks of zero absorption. The bond strengths between zero and about $30 \mathrm{~g}$ suction were highest with mortars of high strength. It is evident also from figure 14, in which the maximum bond strengths

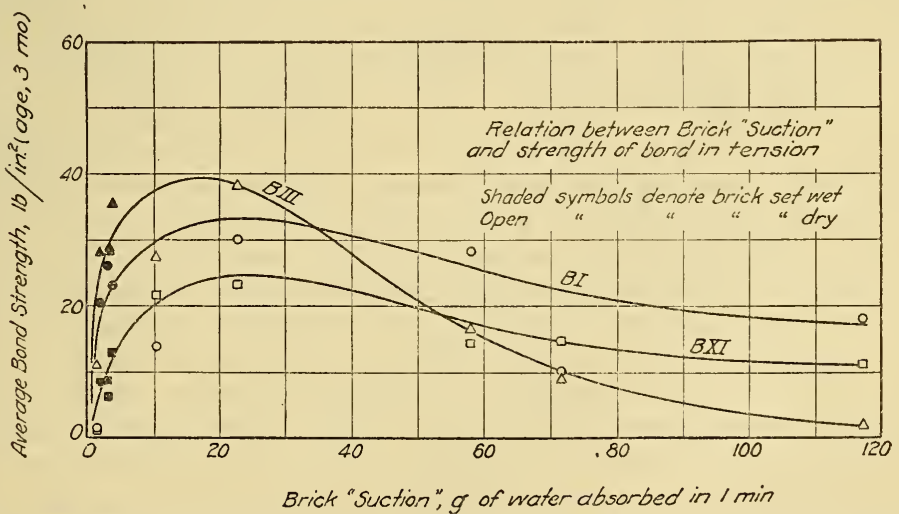

FIGURE 13.-Bond strength as related to brick suction and water-retaining capacity of mortars.

of mortars at 3 months are plotted against the logarithm (base 10) of the compressive strengths of the mortars at 3 months, that the bond strengths were highest with mortars of high strength, provided that the extent of bond was good.

When the brick suction was $60 \mathrm{~g}$ per minute or greater, the highest strength of bond at 3 months was obtained with mortars of medium 
strength and medium or high water-retaining capacity. This is apparent from inspection of the curves in figures 12 and 3 . For example, the curve for mortar A I crosses below the curves for XRa and XRc as the brick suction increased beyond $60 \mathrm{~g}$. Moreover, the curves for mortars XRa and XRc approach one another in this region. Mortar A I had very much higher compressive strength and much lower water-retaining capacity than either mortar XRa or XRc. Mortars XRa and XRc differed more in water-retaining capacity (XRc higher) than in strength (XRa higher).

Bond strength was dependent both on the intensity and extent of adhesion of mortar to bricks. When very low bond strength was obtained with the strongest mortars, inspection of the broken specimens showed the extent of bond to be small, the bonded area being often less than 25 percent of the bonding area. The extent of bond was practically 100 percent in all tests where the brick suction was

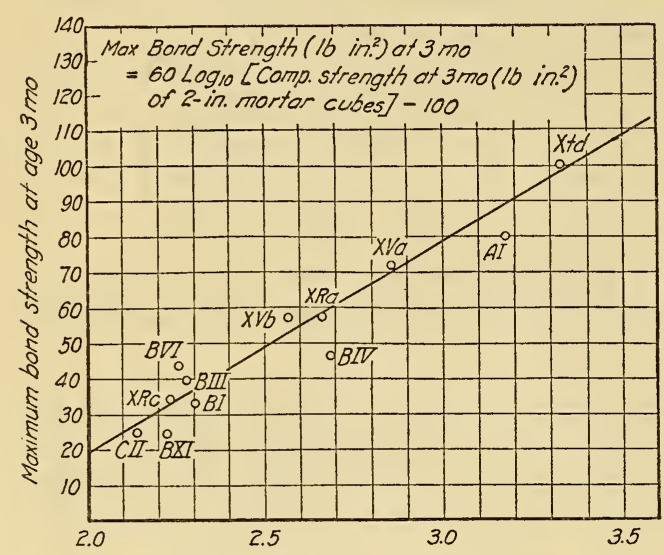

$\log _{10}$ (Compressive strength of mortar at age $3 \mathrm{mo}$ )

Figure 14.-Bond strength as related to compressive strength of mortars at or less than the optimum (about $20 \mathrm{~g}$ ). With the extent of bond as good as this, strength of bond was dependent more on the strength of mortar than on any other single factor. This is apparent from figures 10,11 , and 14 .

(3) The effect of shrinkage on bond strength during early hardening of mortars. Consider mortars A I, XTd, XRa, XVb, XRc, C I, C II, B IV, and $\mathrm{B}$ XI, as used with brick no. 3 (set dry), figure 10, and with brick no. 5 (set dry), figure 11 . The shaded triangle designates the strength of bond in specimens of series $5 \mathrm{~A}$ (tested at 3 months) that contained metal lugs in the mortar joints which theoretically would increase any damage to the bond resulting from early shrinkage. The positions of these points should be compared to those of the open triangles (no lugs, all other conditions the same). In some cases the strength of bond with lugs was actually greater than that obtained without them. The vertical distances between the two triangles are in all cases small and indicate, therefore, that the early shrinkage had no effect on the bond. The absorptions of bricks 3 and 5 were low, that of 5 being nearly zero, hence the shrinkage during early hardening of mortars between these bricks should have been comparable to that measured with the specimens of the same mortars cast in metal molds.

(4) The combined effect of shrinkage during early hardening, and of compacting of mortar on a porous base, on bond strength. The previous section dealt with mortars on a practically nonporous base. Freshly-made mortar begins at once to lose water when placed on a porous base, prior to any appreciable hardening of the mortar and with consequent diminution in volume and this compacting on a por- 
ous base must be distinguished from shrinkage during early hardening which occurs later. Compacting is minimized when the base is a brick of the types no. 3 or no. 5 . However, shrinkage during early hardening would tend to be greater on a nonporous than on a porous base, since reducing the amount of water in mortars tends to reduce this type of volume change (see table 5). Compacting on a porous base is also for the most part unidirectional, i.e., mortar in horizontal joints is compacted chiefly in the vertical direction. Shrinkage attending hardening or cementing action is essentially omnidirectional.

In test series $6 \mathrm{~A}$ (table 4 and figs. 10 and 11) bricks 1,4 , and 6 were set both wet and dry with mortars A I and B III of low, B I and XRa of medium, and XRc and B XI of high water-retaining capacities, respectively. In this series metal lugs were embedded in all mortar joints. Since compacting of mortar on a porous base is a consequence of water loss to the base, it would be expected that mortars of highest water-retaining capacities would compact least. At the same time such mortars in this case (XRc and B XI) are characterized by relatively high shrinkage during early hardening. The reverse was true for mortars A I and B III. Porous bases were obtained with bricks 1,4 , and 6 set dry. The strength of bond at 3 months with this condition (shaded squares, figs. 10 and 11) should be compared with that obtained when the same bricks were set wet (square with cross, same figures). In the first case the conditions were theoretically conducive to a maximum degree of compacting and a minimum degree of shrinkage during early hardening. The reverse was the case with the bricks set wet.

For mortar A I, brick 1 set dry and with lugs (shaded square, figure 10), the strength of bond at 3 months was very low and less than the strength obtained without lugs and all other conditions the same (series $1 \mathrm{~A}$, open circle). The bond strength with no. 1 brick set wet, series $6 \mathrm{~A}$ (square with cross), was only slightly less than that obtained without lugs, all other conditions being the same (series $1 \mathrm{~A}$, shaded circle). In this case, the fact that brick no. 1 was wet or dry when set was of more importance than whether or not lugs were in the mortar joints.

From figures 10 and 11 similar comparisons may be made with each of the mortars A I, B III, B I, XRa, B XI, and XRc and bricks 1,4 , and 6 set both wet and dry, with and without lugs. When these comparisons are made, the following will be evident: no damaging effect on bond strength produced either by compacting on a porous base or by shrinkage during early hardening or by both occurrences was noticeable when metal lugs, designed to increase such an effect by restraining movement (in the vertical direction) of the bricks, were embedded in the joints. A much lower strength of bond was obtained with mortars A I and B III (low water-retaining capacity) with the dry than with the wet bricks whether lugs were or were not present. On the other hand with mortars XRc and B XI (high water retaining capacity), higher bond strengths at 3 months were usually obtained with bricks 1,4 , and 6 set dry with lugs than when these bricks were set wet either with or without lugs. In the case of mortar XRa (medium water-retaining capacity) the bond strength was highest with bricks 1 and 6 set wet and brick 4 set dry. Bricks 1 and 6 each had a higher absorption rate than brick 4 . 
It is indicated by the process of elimination, that the rapid stiffening of mortars of low water-retaining capacity on a porous base, an occurrence always very noticeable with this combination of brick and mortar types, is the main cause of a poor initial bond. The compacting of the mortar in this case is relatively, at least, of far less importance in its effect on bond strength than rapid stiffening, which renders unlikely a desirable intimacy of contact between the mortar and the unit. It is further indicated that with such desirable contact, there is no significant change in the early bond strength produced by even a relatively high degree of shrinkage during early hardening (characteristic of mortars XRc and B XI).

(5) The effect on bond strength of volume changes in mortar subsequent to hardening. The brick-mortar specimens of series $2 \mathrm{~A}$ were subjected to only 3 cycles of alternate wetting for 1 month in the high-humidity room and drying for 3 months in the laboratory (curing $\mathrm{B}$, table 3 ). Those of series $3 \mathrm{~A}$ were subjected to cycles of drying for 18 days in the high-temperature low-hunidity room and then wetting by partial immersion (curing $\mathrm{C}$, table 3 ). Aside from differences in the number of cycles, the degree of wetting and drying and the temperatures during these exposures all conditions were the same in these two test series. The values in table 9, prepared from the data of figures 10 and 11, show that, of the 15 mortars and 6 brick combinations (total of 90 ), the bond strengths at 1 year were higher 57 times for series $3 \mathrm{~A}$ and 31 times for series $2 \mathrm{~A}$.

It is seen from table 9 that with all bricks except no. 2 , the bond strength at 1 year was usually higher in series $3 \mathrm{~A}$. The reverse was true with brick no. 2. Therefore, the strengths were not damaged by the amount of volume change of the mortars subsequent to hardening.

TABLE 9.-A comparison of bond strengths obtained with test series $2 \mathrm{~A}$ and $3 \mathrm{~A}$

[Six tests were made with each brick and mortar combination]

\begin{tabular}{|c|c|c|c|c|c|c|c|}
\hline \multirow{3}{*}{ Mortar } & \multirow{3}{*}{$\begin{array}{l}\text { Volume changes subsequent to } \\
\text { hardening }\end{array}$} & \multicolumn{6}{|c|}{$\begin{array}{c}\text { Test series with which highest bond strength was } \\
\text { obtained }\end{array}$} \\
\hline & & \multicolumn{6}{|c|}{ Brick no. } \\
\hline & & 1 & 2 & 3 & 4 & 5 & 6 \\
\hline AI.. & High... & $3 \mathrm{~A}$ & $2 \mathrm{~A}$ & $3 \mathrm{~A}$ & $2 \mathrm{~A}$ & $3 \mathrm{~A}$ & $2 \mathrm{~A}$ \\
\hline $\begin{array}{l}\text { XTd } \\
\text { XRa... } \\
\text { XVa... } \\
\text { XVb... } \\
\text { XRc... }\end{array}$ & Intermediate. & $\begin{array}{l}3 \mathrm{~A}^{2 \mathrm{~A}} \\
3 \mathrm{~A} \\
3 \mathrm{~A} \\
3 \mathrm{~A}\end{array}$ & $\begin{array}{l}2 \mathrm{~A} \\
2 \mathrm{~A} \\
2 \mathrm{~A} \\
2 \mathrm{~A} \\
2 \mathrm{~A}\end{array}$ & $\begin{array}{l}3 \mathrm{~A} \\
3 \mathrm{~A} \\
3 \mathrm{~A} \\
3 \mathrm{~A} \\
3 \mathrm{~A}\end{array}$ & $\begin{array}{l}3 \mathrm{~A} \\
3 \mathrm{~A} \\
3 \mathrm{~A} \\
3 \mathrm{~A} \\
\end{array}$ & $\begin{array}{l}3 \mathrm{~A} \\
3 \mathrm{~A} \\
3 \mathrm{~A} \\
3 \mathrm{~A} \\
3 \mathrm{~A}\end{array}$ & $\begin{array}{l}3 \mathrm{~A} \\
3 \mathrm{~A} \\
3 \mathrm{~A} \\
3 \mathrm{~A} \\
3 \mathrm{~A}\end{array}$ \\
\hline $\begin{array}{l}\text { CI--- } \\
\text { CII.-- } \\
\text { CIII.- } \\
\text { CIV-- }\end{array}$ & $\begin{array}{l}\text { Low } \\
- \\
- \text { do }_{-}\end{array}$ & $\begin{array}{l}3 \mathrm{~A} \\
3 \mathrm{~A} \\
3 \mathrm{~A} \\
3 \mathrm{~A}\end{array}$ & $\begin{array}{l}3 \mathrm{~A} \\
3 \mathrm{~A} \\
\text { tie }\end{array}$ & $3^{2 \mathrm{~A}} \mathrm{~A}^{2 \mathrm{~A}}$ & $\begin{array}{l}3 \mathrm{~A}^{2 \mathrm{~A}} \\
3 \mathrm{~A}\end{array}$ & $\begin{array}{l}3 \mathrm{~A} \\
3 \mathrm{~A}^{2 \mathrm{~A}} \\
3 \mathrm{~A}\end{array}$ & $\begin{array}{ll} & 2 \mathrm{~A} \\
3 \mathrm{~A} & 2 \mathrm{~A} \\
3 \mathrm{~A} & \end{array}$ \\
\hline $\begin{array}{l}\text { BI } \\
\text { BIII--- } \\
\text { BIV--- } \\
\text { BVI--- } \\
\text { BXI-.- }\end{array}$ & $\begin{array}{l}\text { Intermediate- } \\
\text { Low__ } \\
\text { Intermediate } \\
\text { High }\end{array}$ & $\begin{array}{l}\text { tie } \\
3 \mathrm{~A} \\
3 \mathrm{~A} \\
3 \mathrm{~A} \\
3 \mathrm{~A}\end{array}$ & $\begin{array}{l}2 \mathrm{~A} \\
2 \mathrm{~A} \\
2 \mathrm{~A} \\
2 \mathrm{~A} \\
2 \mathrm{~A}\end{array}$ & $\begin{array}{l}3 \mathrm{~A} \\
2 \mathrm{~A} \\
3 \mathrm{~A}^{2 \mathrm{~A}} \\
3 \mathrm{~A}\end{array}$ & ${ }_{3 A^{2 A}}{ }^{2 A}$ & $\begin{array}{l}3 \mathrm{~A} \\
3 \mathrm{~A} \\
3 \mathrm{~A} \\
3 \mathrm{~A} \\
3 \mathrm{~A}\end{array}$ & $\begin{array}{lr}3 \mathrm{~A} & \\
& 2 \mathrm{~A} \\
3 \mathrm{~A} & \\
3 \mathrm{~A} & \\
& 2 \mathrm{~A}\end{array}$ \\
\hline
\end{tabular}

It must not be concluded though that with different sands and cements or with mortars richer in cements than those herein described, there could be no damage to the bond through volume changes in the hardened mortars. ${ }^{29}$

${ }^{20}$ See reference, footnote 2 . 
Inspection of the broken specimens, series $3 \mathrm{~A}$ and $2 \mathrm{~A}$, showed good extent of bond in all cases. Unbonded areas were altogether lacking, a condition not always realized in walls of buildings. There were more surface cracks on mortar joints with mortars A I, XTd, XRa, XVa, and B IV, series $3 \mathrm{~A}$, than were noted with these nortars in series $2 \mathrm{~A}$. Such cracks, however, which developed during drying, tended to heal during wetting.

(6) The increase in strength of bond with time. That bond strength increased with time is evident from figures 10 and 11 when a part of series $1 \mathrm{~A}$ is compared with all of series $2 \mathrm{~A}$. All specimens of series $1 \mathrm{~A}$ were tested at 3 months and

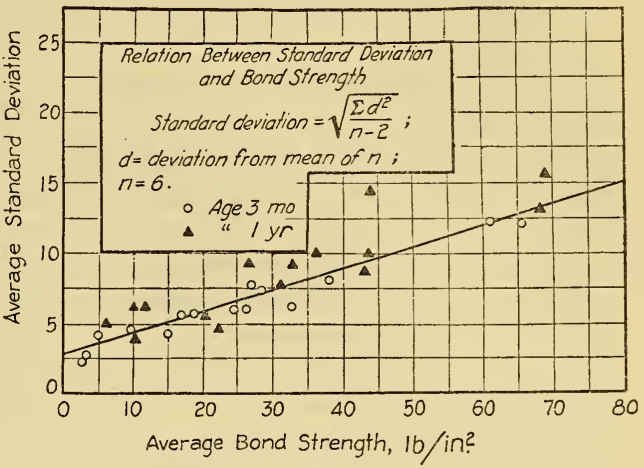

Figure 15.-Average standard deviations computed from test series $1 A$ and $2 A$ as related to average bond strength obtained with 15 mortars and 6 makes of bricks. those of $2 \mathrm{~A}$ at 1 year. Note first the relative positions of the shaded circles and the open squares with bricks $1,2,4$, and 6 (set wet), then those of the open circles and open squares with bricks 3 and 5 (set dry). The vertical distances

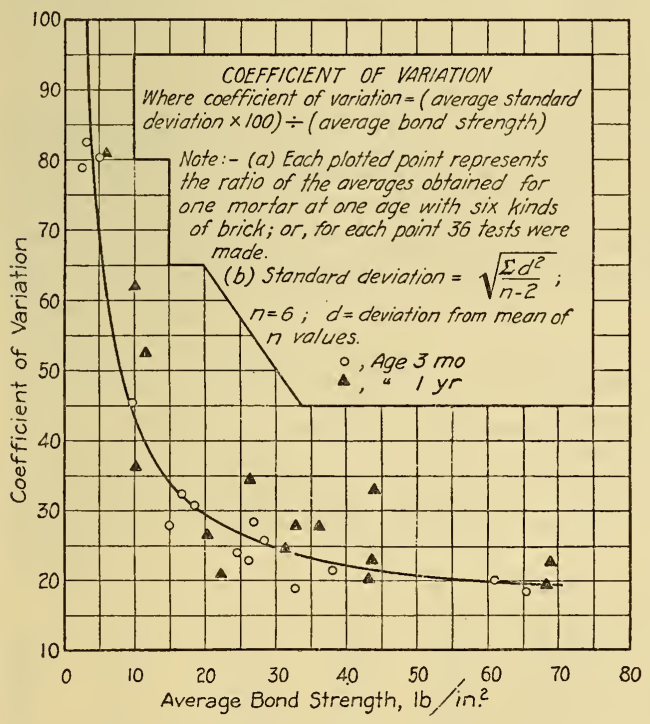

FIgURE 16.-Coefficients of variation compuied from the data plotted in figure 15 between the points as indicated varied with the mortar, being generally proportional to the corresponding increase in compressive strength of mortar cubes from 3 months to 1 year (figs. 3 and 4 ). In a very few instances (mortars B VI and B I with brick no. 1) the bond strength at 3 months was appreciably greater than at 1 year.

(7) Statistical treatinent of bond strength data. Figures 15 and 16 show a relation between bond strength and standard deviation. In obtaining these relations only those specimens in which the extent of bond (noticed on inspection of the broken specimens) was good and for which all conditions including exposure and method of making the specimens were the same have been considered. The results included in the computations, therefore, were those obtained with bricks $1,2,4$, and 6 set wet with all mortars and bricks 3 and 5 (relatively impervious) set dry with all mortars. This included a part of series 1A (3-month tests) and all of series $2 \mathrm{~A}$ (1-year tests). 
A value was obtained for the standard deviation for each mortar and brick combination and for each of the two test ages (3 months and a year) with the formula: ${ }^{30}$

$$
\text { Standard deviation }=\sqrt{\frac{\Sigma d^{2}}{n-2}}
$$

In this formula, $\Sigma d^{2}$ is the sum of the squares of the 6 deviations from the mean of $n$ (equal to 6) tests, the number of tests made with 1 brick and mortar combination and at a definite age, 3 months or a year. In figure 15 the average of 6 standard deviations as computed above, all for the same mortar and age but with all 6 makes of brick, is plotted against the average of the 6 corresponding bond strength averages. Each plotted point, therefore, represents the results of tests of 36 test specimens (1 age, 1 mortar, 6 makes of brick).

The coefficients of variation, figure 16 (representing coefficient of variation as related to average bond strength) are the ratios, average standard deviation,

average bond strength multiplied by 100 .

It is seen in figure 16 that the coefficient of variation increases most rapidly with decreasing bond strength for average bond strengths less than $20 \mathrm{lb} /$ in. $^{2} \quad$ For strength above this value, the change in coefficient of variation is less marked. By selecting materials and conditions such that a bond strength of 20 pounds or more per square inch may reasonably be expected, fairly reproducible and representative bond strength values could be obtained with a fewer number of specimens than would be required when working with materials and conditions likely to yield bond strengths below this value.

\section{(b) DURABILITY OF BOND}

Test series $4 \mathrm{~A}, 7 \mathrm{~A}, 8 \mathrm{~A}$, and $1 \mathrm{~B}$ (table 4 ) were made for the purpose of studying bond durability. Of series $7 \mathrm{~A}$, including all bricks and all of the 15 mortars, there were only two cases of bond failure during a year of alternate wetting and drying that preceded the freezing and thawing tests. These failures occurred with mortar B XI used with brick no. 1 and C I with brick no. 6, set wet. Both mortars were of low strength.

The results obtained with test series $7 \mathrm{~A}$ are summarized in table 10.

TABLE 10.-Bond durabi ${ }^{7}$ ity of 2 brick-mortar specimens (series 7A).

\begin{tabular}{|c|c|c|c|c|c|c|c|}
\hline \multirow{3}{*}{ Mortar } & \multicolumn{6}{|c|}{$\begin{array}{c}\text { Total number of freezing and thawing cycles endured with } \\
\text { out bond failure by } 3 \text { specimens }\end{array}$} & \multirow{3}{*}{ Average } \\
\hline & \multicolumn{6}{|c|}{ Brick number } & \\
\hline & 1 & 2 & 3 & 4 & 5 & 6 & \\
\hline $\begin{array}{l}\text { A I I } \\
\text { XTd } \\
\text { X Ra } \\
\text { X Va } \\
\text { XVb } \\
\text { X Re } \\
\text { C I I } \\
\text { C II } \\
\text { C III } \\
\text { C IV } \\
\text { B I I } \\
\text { B III } \\
\text { B IV } \\
\text { B VI } \\
\text { B XI }\end{array}$ & $\begin{array}{r}105 \\
105 \\
58 \\
65 \\
15 \\
14 \\
30 \\
50 \\
14 \\
6 \\
88 \\
105 \\
105 \\
105 \\
0\end{array}$ & $\begin{array}{r}105 \\
105 \\
70 \\
83 \\
27 \\
23 \\
26 \\
85 \\
32 \\
28 \\
73 \\
105 \\
105 \\
105 \\
57 \\
\end{array}$ & $\begin{array}{r}105 \\
105 \\
105 \\
105 \\
105 \\
76 \\
13 \\
48 \\
20 \\
12 \\
105 \\
105 \\
105 \\
105 \\
105 \\
\end{array}$ & $\begin{array}{r}105 \\
105 \\
54 \\
105 \\
10 \\
11 \\
2 \\
6 \\
7 \\
0 \\
105 \\
105 \\
105 \\
105 \\
105\end{array}$ & $\begin{array}{r}105 \\
105 \\
105 \\
105 \\
105 \\
47 \\
2 \\
9 \\
9 \\
9 \\
36 \\
105 \\
105 \\
105 \\
35\end{array}$ & $\begin{array}{r}105 \\
105 \\
83 \\
84 \\
21 \\
17 \\
0 \\
7 \\
7 \\
7 \\
105 \\
105 \\
105 \\
105 \\
6 \\
\end{array}$ & $\begin{array}{r}105 \\
105 \\
79 \\
91 \\
47 \\
31 \\
12 \\
34 \\
15 \\
10 \\
85 \\
105 \\
105 \\
105 \\
51\end{array}$ \\
\hline Average & $\overline{58}$ & $\overline{69}$ & $\overline{81}$ & 62 & 66 & 57 & $\overline{65}$ \\
\hline
\end{tabular}

${ }^{30}$ Biometrika, vol. 10, p. 525. 
The number of cycles of freezing and thawing endured without failure given in table 10 is computed by adding the total number of cycles endured by the three like specimens. If one specimen should survive only 13 and the other two 35 cycles, the total number of cycles endured would be 83 as in the case of mortar XVa and brick no. 2 . The number, 105, is, therefore, a perfect record and a diminution in total number of cycles endured shows a lessened bond durability under the conditions of test.

Bond durability decreased as more and more lime was substituted for portland cement, the record of XRC, a 1PC:3L:12S mortar being about the same as that of C II, a straight lime-sand mortar. On the basis of approximate strength equality, mortars XRa, XVa and XVb should have been as resistant to freezing and thawing as masonry cement mortars B III, B IV, and B VI which was not the case. There is also another factor to be considered. It is observed (fig. 7) that the sorption of these portland-cement-lime mortar mixtures exceeded that of mortars of masonry cements nos. 3, 4, and 6. The data indicate, therefore, that the two properties, strength and sorption of mortars, were of primary importance in getting bond durability.

Excepting brick no. 3, the average number of bond failures did not vary appreciable with the make of brick. Brick no. 5 set dry had a lower absorption rate than bricks $1,2,4$, and 6 set wet. Brick 3 , also set dry, had an absorption rate somewhat greater than that of the bricks set wet. As indicated in figures 12 and 13, a certain degree of absorption is, within limits, a factor that improves the strength of bond, possibly by increasing the mortar strength (by increasing the cement-water ratio), yet without removing too much of the water from the mortar. This condition was more closely approached by brick 3 set dry in series 7A than by any of the other bricks of that series. This again indicates that an increase in strength of mortar is attended by an increase in bond durability, all other conditions being the same.

The fact that the averages in table 10 of bricks 1 and 6 were lower than those of bricks 2,4 , and 5 may possibly be explained by the fact that the bonding areas of bricks 2,4 , and 5 were more rough and uneven than those of bricks 1 and 6 .

The percentage failures of specimens of test series 8A (mortars A I, B I, B IV, B XI, XRa, and XRc with bricks 2, 3, and 4) which were a month old when first subjected to freezing and thawing is compared in table 11 with the corresponding percentage failures of specimens of the same mortar and brick combinations (included in test series $7 \mathrm{~A}$ ) that had aged a year when freezing and thawing was begun.

TABLE 11.-Percentage of specimen failures

\begin{tabular}{|c|c|c|c|c|c|c|}
\hline \multirow{3}{*}{ Mortar } & \multicolumn{6}{|c|}{ Percentage failures during 35 cycles of freezing and thawing } \\
\hline & \multicolumn{2}{|c|}{ Brick no. 2, aged } & \multicolumn{2}{|c|}{ Brick no. 3, aged } & \multicolumn{2}{|c|}{ Brick no. 4, aged } \\
\hline & 1 month & 1 year & 1 month & 1 year & 1 month & 1 year \\
\hline 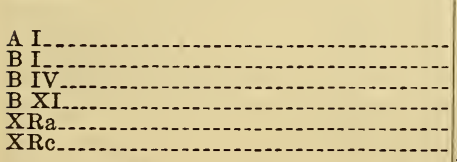 & \begin{tabular}{|r|} 
Percent \\
0 \\
17 \\
0 \\
33 \\
0 \\
1100 \\
\end{tabular} & $\begin{array}{r}\text { Percent } \\
0 \\
33 \\
0 \\
67 \\
33 \\
2100 \\
\end{array}$ & $\begin{array}{r}\text { Percent } \\
0 \\
17 \\
0 \\
33 \\
17 \\
1100 \\
\end{array}$ & $\begin{array}{r}\text { Percent } \\
0 \\
0 \\
0 \\
0 \\
0 \\
33 \\
\end{array}$ & $\begin{array}{r}\text { Percent } \\
0 \\
0 \\
0 \\
50 \\
0 \\
83 \\
\end{array}$ & $\begin{array}{r}\text { Percent } \\
0 \\
0 \\
0 \\
0 \\
33 \\
2100 \\
\end{array}$ \\
\hline A verage_.. & 25 & 39 & 28 & 6 & 22 & 28 \\
\hline
\end{tabular}

1 No failures during first 10 cycles of freezing and thawing.

2 At least 1 specimen survived first 10 cycles of freezing and thawing. 
The results (table 11) do not indicate an increase in resistance to freezing and thawing with aging specimens except in the case of brick no. 3 .

The results obtained with test series $4 \mathrm{~A}$ are presented in table 12. In this instance brick suction was controlled by partially immersing 5 groups each of 24 bricks for $0,1 / 4,1,3,5$, and 15 minutes, respectively. The average suction (g of water per minute per $30 \mathrm{sq}$ in.) was $58 \mathrm{~g}$ for bricks set dry and $40,26,16,12$, and $3.3 \mathrm{~g}$ after partial immersion for $1 / 4,1,3,5$, and 15 minutes, respectively.

\section{TABLE 12.-The strength of bond of specimens of test series $4 \mathrm{~A}$}

[Each average value was obtained with 12 specimens]

Mortar XRa and brick no. 4

\begin{tabular}{|c|c|c|c|c|c|}
\hline Group & $\begin{array}{l}\text { Brick suc- } \\
\text { tion }\end{array}$ & $\begin{array}{l}\text { Average } \\
\text { bond } \\
\text { strength }\end{array}$ & $\begin{array}{l}\text { Individual } \\
\text { maximum }\end{array}$ & $\begin{array}{l}\text { Individual } \\
\text { minimum }\end{array}$ & $\begin{array}{l}\text { Total area } \\
\text { of section of } \\
\text { failure rep- } \\
\text { resented by } \\
\text { failure of } \\
\text { brick }\end{array}$ \\
\hline $\begin{array}{l}\text { No. } 1 \\
\text { No. } 2 \\
\text { No. } 3 \\
\text { No. } 4 \\
\text { No. } 5 \\
\text { No. } 6\end{array}$ & $\begin{array}{l}g \\
58 \\
40 \\
26 \\
16 \\
12 \\
3.3\end{array}$ & $\begin{array}{r}\text { Lb/in. }{ }^{2} \\
49.2 \\
48.6 \\
50.9 \\
50.8 \\
55.9 \\
45.2\end{array}$ & $\begin{array}{r}\text { Lb/in. } .^{2} \\
75.5 \\
69.4 \\
68.3 \\
78.4 \\
81.5 \\
67.1\end{array}$ & $\begin{array}{r}\text { I.b/in. }{ }^{2} \\
30.8 \\
32.4 \\
23.1 \\
22.2 \\
37.8 \\
1.0\end{array}$ & $\begin{array}{r}\text { Avg per } \\
\text { centage } \\
25 \\
19 \\
35 \\
40 \\
10 \\
0\end{array}$ \\
\hline
\end{tabular}

1 Failed during freezing and thawing.

After 35 freezing and thawing cycles (with intermittent drying after each 5 cycles) the specimens of test series $4 \mathrm{~A}$ were tested for strength of bond in tension. The bricks were apparently weakened by freezing and thawing to a degree such that their strength in tension was not much greater than that of the mortar. The percentage failure in the brick when the specimen broke in tension was estimated as carefully as possible for each of the 12 specimens of a group and the averages of these percentages are recorded in column 6 of table 12 . In specimens made with brick no. 4, not subjected to freezing and thawing and tested for bond strength, the bricks were almost invariably stronger in tension than mortar XRa.

The data (table 12) show that best results were obtained with bricks having a suction from 12 to $40 \mathrm{~g}$ per minute. The average bond strength values do not differ to the extent characteristic of the 3 months strength of bond data (fig. 12) and this fact may indicate that factors other than early bond strength affect the bond durability. The individual variations (maximum and minimum values, table 12 ) were somewhat greater than would be predicted from the plotted data of figure 16 where specimens not subjected to durability tests are considered. This indicates partial or complete destruction of bond by alternate freezing and thawing.

No bond failures occurred in test series $1 \mathrm{~B}$ (table 4 ). The presence of vertical joints in these specimens did not render them less resistant to freezing and thawing than the specimens without vertical joints.

It is difficult to devise a freezing and thawing test that may be generally considered as paralleling exposures of walls. The tests described herein were probably unduly severe insofar as those mortars 
which gain strength relatively slowly are concerned and fair to the mortars of outstanding hydraulic properties. It is a well-known fact that mortars of many of the natural cements require many years for the development of any large percentage of their ultimate strength. The same is true for lime and rich in lime mortars. In buildings, many cycles of freezing and thawing of the water within the masonry are completed far more slowly than is the case in such laboratory tests and hence in practice, there is far less likelihood of damage to the mortar prior to its attainment of higher strength with consequent increased resistance to weathering than obtains in the laboratory tests. Furthermore, the procedure, thawing specimens under water, has no parallel in conditions obtaining in walls generally, and is likely only indicative of what may be expected of masonry below grade and in a severe climate. A satisfactory weathering test is at the best a moot subject and this fact should be borne in mind in reviewing the data here presented.

\section{(c) THE TRANSVERSE STRENGTH OF BRICK BEAMS}

The results of the flexure tests with specimens of test series $1 \mathrm{C}$ and $2 \mathrm{C}$ (table 4) are presented in table 13.

TABLE 13.-Transverse tests of brick beams ( 5 bricks, single tier, 4 intervening mortar joints)

[Values are averages of 3 tests]

\begin{tabular}{|c|c|c|c|c|c|c|c|c|c|c|c|c|}
\hline \multirow{3}{*}{ Mortar } & \multicolumn{12}{|c|}{ Modulus of rupture, brick number- } \\
\hline & \multicolumn{2}{|c|}{1 (set wet) } & \multicolumn{2}{|c|}{2 (set wet) } & \multicolumn{2}{|c|}{3 (set dry) } & \multicolumn{2}{|c|}{4 (set wet) } & \multicolumn{2}{|c|}{5 (set dry) } & \multicolumn{2}{|c|}{6 (set wet) } \\
\hline & $\begin{array}{c}3 \\
\text { months }\end{array}$ & $\begin{array}{c}1 \\
\text { year }\end{array}$ & $\begin{array}{c}3 \\
\text { months }\end{array}$ & $\begin{array}{c}1 \\
\text { year }\end{array}$ & $\stackrel{3}{\text { months }}$ & $\stackrel{1}{\text { year }}$ & $\begin{array}{c}3 \\
\text { months }\end{array}$ & $\begin{array}{c}1 \\
\text { year }\end{array}$ & $\begin{array}{c}3 \\
\text { months }\end{array}$ & $\begin{array}{c}1 \\
\text { year }\end{array}$ & $\begin{array}{c}3 \\
\text { months }\end{array}$ & $\begin{array}{c}1 \\
\text { year }\end{array}$ \\
\hline & Lb/in.2 & Lb/in.2 ${ }^{2}$ & Lb/in..$^{2}$ & Lb/in..$^{2}$ & Lb/in. ${ }^{2}$ & Lb/in..$^{2}$ & Lb/in.2.$^{2}$ & Lb/in..$^{2}$ & Lb/in. ${ }^{2}$ & Lb/in. ${ }^{2}$ & Lb/in.2. & $L b / i n . .^{2}$ \\
\hline & $\begin{array}{l}1 \\
119.7\end{array}$ & $\begin{array}{l}115.2 \\
130.6\end{array}$ & $\begin{array}{r}208.0 \\
1132.3\end{array}$ & $\begin{array}{r}119.8 \\
171.1\end{array}$ & $\begin{array}{l}139.4 \\
138.8\end{array}$ & $\begin{array}{l}166.4 \\
215.4\end{array}$ & $\begin{array}{l}100.7 \\
126.0\end{array}$ & $\begin{array}{r}144.8 \\
1128.2\end{array}$ & $\begin{array}{r}18.2 \\
14.1\end{array}$ & $\begin{array}{l}189.1 \\
166.7\end{array}$ & $\begin{array}{r}10.0 \\
11149.2\end{array}$ & $\begin{array}{l}1123.7 \\
1155.3\end{array}$ \\
\hline & 56.6 & 93.9 & 66 & 49.5 & 73.5 & 158 & 90.5 & 92 & 15.8 & 147.0 & 104.7 & 15 \\
\hline & 42. & & 47 & 70 & 68. & 179 & & 81 & 6. & & 122.9 & 148. 3 \\
\hline & 45. & & 42. & 46 & 39. & 157. & 83 & 106 & 10. & & 88 & 9 \\
\hline & 29. & 45. & 24. & 21. & 30. & 57. & 35. & 35. & 15. & 43 & 42. & 46.8 \\
\hline & 2. & & 2. & 26 & 2. & 2. & 2. & 13. & 2. & & 0 & 4 \\
\hline C & 28. & & 32. & 63 & 39. & 19. & 26. & 7. & 13. & & 32.9 & 51.2 \\
\hline & 2.0 & 27 . & 2. & 28. & 2. & 11 & 2. & 14. & 2 . & & 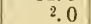 & 19.5 \\
\hline & 2.0 & 29 & 2. & 31 & 2. & 10 & 2. & & 2. & & & 2 \\
\hline & 18.1 & & 39. & 36 & 13. 5 & & $47^{\circ}$ & 77 & 12. & 23 & ${ }^{1} 1$ & 40.6 \\
\hline II & 119.9 & 65. & 42.1 & 83. & 133.2 & 136 & 34 & 47. & 13. & 20 & 118.2 & 48.8 \\
\hline & 1.0 & 1. & 66. & 110. & ${ }^{1} 36.6$ & 97 & 17. & 11. & 13. & 80 & ${ }^{1} 1.0$ & 8 \\
\hline$Y$ & 40.8 & 60. & 36. & 6 & 68.5 & 129. & 61. & 82. & 21. & & 68 & 129.1 \\
\hline $\mathrm{BX}$ & 12.9 & 17 & 11.9 & 16 & 14.8 & & 16.1 & 30 & 1.6 & & 18. 3 & 16.7 \\
\hline A verag & 23.1 & 59.2 & 50.0 & 62.5 & 33.1 & 84.7 & 47.9 & 58.4 & 7.4 & 54.9 & 43.2 & 70.2 \\
\hline
\end{tabular}

1 Poor extent of bond obtained with at least one of the test specimens.

2 All 3 beams failed prior to the time of testing, extent of bond good, failure in the mortar.

The most concordant results (table 13) were obtained with mortars $\mathrm{XRa}, \mathrm{XVa}, \mathrm{XVb}, \mathrm{XRc}, \mathrm{B}$ III, and B VI and with bricks 1, 2, 3, 4, and 6. These mortars were of low (B III), intermediate (XRa and $\mathrm{XVa})$, and high $(\mathrm{XVb}, \mathrm{XRc}$, and $\mathrm{B} V \mathrm{VI})$ water retaining capacities. Where low values were obtained with mortars A I, XTd, and B IV (high strength and low water-retaining capacity), 1 or more of the 3 beams failed prior to the time of test. Mortars A I, XTd, and B IV had low shrinkage during early hardening, and high volume changes subsequent to hardening. Failure in such cases was at the juncture of brick and mortar joint and on inspection it was seen that only portions of the bonding areas of the bricks had been bonded 
initially. When there is such a poor extent of bond it may be possible that volume changes in the mortar may break it. It is difficult to account for such instances of failure on any other basis.

The poor extent of bond was likely caused by the fact that the mortars of low water-retaining capacity tend to lose water on standing. This was not due to suction, as in making the beams all bricks having any appreciable suction were first wetted. The water in the mortars of low water-retaining capacities tended to separate out from the solid material while it remained on a brick and prior to pressing down the next higher brick of the test specimen. The time taken to put bricks in place was longer in the case of the 5-brick beams than it was in making the 2-brick mortar specimen. In the latter case there was not time for the mortars to lose water before the top brick was placed.

Inspection of broken specimens showed clean areas on the bottoms of upper bricks corresponding to depressed areas on the mortar beds where water had collected when the beam was made. In this connection "water-carrying capacity" has been discussed in a previous publication ${ }^{31}$ and it was observed that the mortars of low waterretaining capacity had also usually low water-carrying capacity.

Failure was for the most part in the mortar itself in the case of mortars XRa, XVa, XVb, XRc, and B VI. In these instances separation of water from solid on standing did not occur and the bond between brick and mortar was stronger than the mortar, both at 3 months and a year. This was true also for the straight lime-sand mortars, but in this case it was impossible to move the specimens from one storage to another during the early aging period without causing failures in the mortar.

Mortar B III was to some extent unique in that it exhibited low water-retaining capacity on a porous base and yet had relatively less tendency to lose water by segregation when on an impervious base than the other mortars of low water-retaining capacity. Mortar B III was characterized by low-volume changes subsequent to hardening (see fig. 2). Failure with this mortar was usually at the juncture of brick and mortar, as was also the case with mortars B I and B XI, both highly stearated and of high water-retaining capacity. It is believed that the quantities of water-repellent materials in mortars B I and B XI may have been excessive and that at the time of making the specimens, this prevented the desirable degree of contact between the cementing material and the brick surface.

Brick no. 5 was semivitrified and smoother than most side-cut bricks, and there were more failures at the juncture of brick and mortar with this brick than with any of the other five.

\section{(d) COMPRESSIVE STRENGTH OF BRICK PIERS}

Those 3-brick portions of the beams that remained intact when the beams were broken were tested for compressive strength. Typical results are given in figure 17 where the compressive strengths of piers a year old are plotted against the compressive strengths of the six makes of brick. Mortars B XI, XRa, and A I were representative of the mortars of low, intermediate, and high compressive strengths, respectively. The data for the other mortars fall on curves of approximately the shape of those shown and lie for the most part between the curves for mortars B XI and A I.

31 See footnote 8. 
The plotted data, figure 17, show that the compressive strength of the piers increased relatively more with increased compressive strength of brick where mortar of high compressive strength (AI) was used than was the case when the mortars were of low (BXI) or intermediate (XRa) compressive strength. To get the fullest effect of brick strength on pier strength it would be necessary to use a mortar of relatively high compressive strength. At the same time the results obtained with relatively weak mortars, such as BXI, were not markedly different from mortars of intermediate strength (XRa). The terms low, intermediate, and high as here used are merely relative and refer only to the mortars described herein.

In testing the three brick piers in compression it was observed that all mortars except AI and X'Td crumbled prior to failure of the piers. The approximate loads to which the mortar cracked and fell away

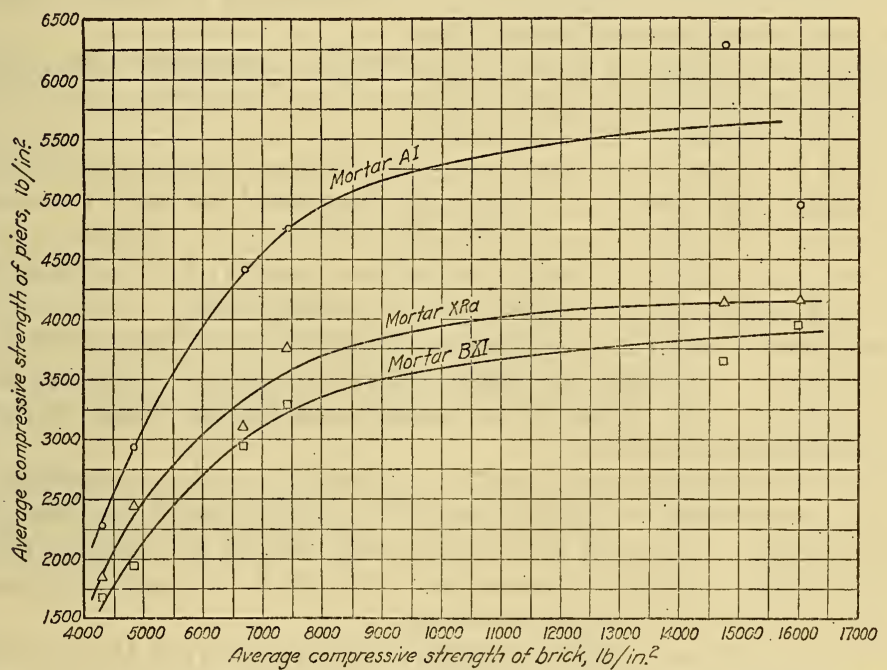

FIGURE 17.-Compressive sirength of brick piers as related to the compressive strength of bricks.

at the edges of the joints were recorded. The ration of the load at which mortar apparently failed to the load at which the pier failed varied from approximately one-third with the weakest mortars (straight lime-sand mortars) to unity with mortars AI and XTd. With mortars of intermediate strength (XRa, XVa, BIV, etc.) the ratio often closely approximated unity, but was usually between three-fourths and four-fifths.

\section{SUMMARY AND CONCLUSIONS}

It must not be considered that the results of this study are final and the following conclusions are applicable only to the conditions, materials, proportions, and types of specimens described.

1. The exten of bond was affected by the properties of both mortars and bricks, but chiefly by the water-retaining capacities of the mortars and the absorption rates of the bricks.

2. With bricks of high rates of absorption set dry, the extent and in most cases the strength of bond was best with mortars of high waterretaining capacity. 
3. Although the extent of bond was good (practically complete), the strength of bond obtained with very impervious bricks (no. 5) having smooth, glassy, bonding surfaces was generally lower than that obtained with the other makes of bricks.

4. Rough surfaced bricks with low rates of absorption, and mechanically smooth and porous bricks made practically nonabsorptive by soaking in water gave good extent of bond when time in brick laying was not permitted for the water in mortars of low water-retaining capacity to separate out. When such time was allowed, the extent of bond was poor ${ }^{32}$ with the mortars of low water-retaining capacity.

5. The maximum bond strength at 3 months was obtained in the case of all mortars with bricks having a rate of absorption of approximately $20 \mathrm{~g}$ of water per $30 \mathrm{sq}$ in. of brick surface per minute when partially immersed (flatside down) to a depth of one-eighth inch in water. This does not imply that the maximum extent of bond was obtained with this rate of absorption.

6 . When the extent of bond is practically complete, the results do not indicate an appreciable weakening of the bond through shrinkage of the mortar during early hardening.

7. There is no evidence that volume changes in mortar subsequent to hardening destroyed or weakened the bond either in vertical or horizontal joints, when the extent of bond is good. When the extent of bond is poor, there is some indication that volume changes subsequent to hardening were destructive to the bond.

8. The bond with mortars of low sorption and high strength was most resistant to alternate freezing and thawing. In the study of bond durability only impervious bricks and bricks made nonabsorptive by wetting were used.

9. From the standpoint of bond durability and considering all of the mortars included in this study, it is indicated that best results may be generally obtained by keeping the rate of absorption of bricks below the value, $40 \mathrm{~g}$ of water, as obtained by partial immersion (flatside down) for 1 minute in water.

10. The maximum bond strength at 3 months with the 15 different mortars increased with the compressive strength of the mortars as determined at 3 months, the conditions of curing the brick mortar specimens and the mortar cubes being the same, provided that the extent of bond was good.

11. With bricks of low rates of absorption and porous bricks made practically nonabsorptive by wetting, the highest bond strength was obtained with mortars of highest strength, when the extent of bond was good.

12. The data indicate that mortars of widely different compositions may have similar properties.

13. The data further indicate that a poor extent of bond may be obtained with certain combinations of bricks and mortars simply because the two materials are not well suited to one another and not because of any defect that would be apparent from tests according to present-day specifications.

Washington, March 14, 1934.

${ }^{32}$ Less tban 90 percent of the bonding area. 